\title{
Radiological Dose Assessment for the Dismantlement and Decommissioning Option for the Heavy Water Components Test Reactor Facility at the Savannah River Site, Aiken, South Carolina
}

\section{E.R. Faillace, S. Kamboj, C. Yu, and S.-Y. Chen}

Environmental Assessment Division,

Argonne National Laboratory, 9700 South Cass Avenue, Argonne, Illinois 60439

October 1997

Work sponsored by U.S. Department of Energy, Savannah River Site, Aiken, South Carolina

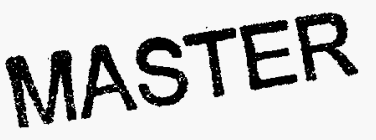




\section{Argonne National Laboratory}

Argonne National Laboratory, with facilities in the states of Illinois and Idaho, is owned by the United States Government, and operated by the University of Chicago under the provisions of a contract with the Department of Energy.

This technical memo is a product of Argonne's Environmental Assessment Division (EAD). For information on the division's scientific and engineering activities, contact:

Director, Environmental Assessment Division

Argonne National Laboratory

Árgonne, Illinois 60439-4815

Telephone (630) 252-3107

Presented in this technical memo are preliminary results of ongoing work or work that is more limited in scope and depth than that described in formal reports issued by the EAD.

Publishing support services were provided by Argonne's Information and Publishing Division (for more information, see IPD's home page: http://www.ipd.anl.gov/).

\section{Disclaimer}

This report was prepared as an account of work sponsored by an agency of the United States Government. Neither the United States Government nor any agency thereof, nor any of their employees, makes any warranty, express or implied; or assumes any legal liability or responsibility for the accuracy, completeness, or usefulness of any information, apparatus, product, or process disclosed, or represents that its use would not infringe privately owned rights. Reference herein to any specific commercial product, process, or senvice by trade name, trademark, manufacturer, or otherwise, does not necessarily constifute or imply its endorsement, recommendation, or favoring by the United States Government or any agency thereof. The views and opinions of authors expressed herein do not necessarily state or reflect those of the United States Government or any agency thereof. 
Gs

This report is printed on recycled paper. 


\section{DISCLAMIER}

Portions of this docoment migy be illegibie in electronic image produets. Images are produced from the best available original document. 


\section{CONTENTS}

NOTATION

ABSTRACT

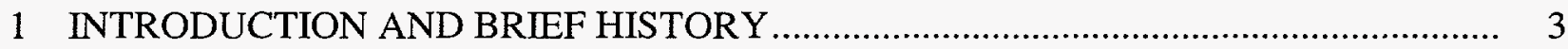

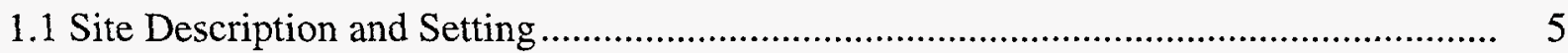

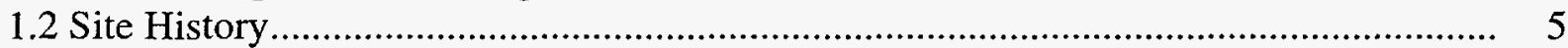

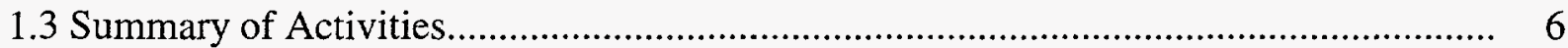

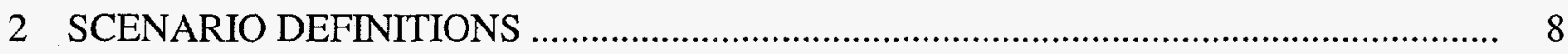

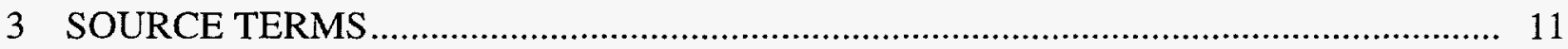

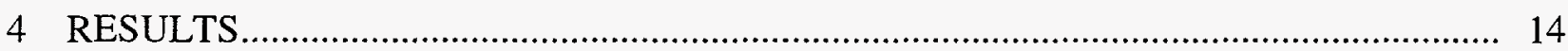

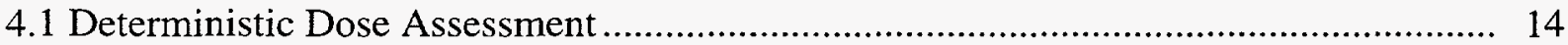

4.2 Parameter Sensitivity Analysis ........................................................................ 14

5 COMPARISON WITH RESULTS OF SMITH AND MCNEIL .................................... 22

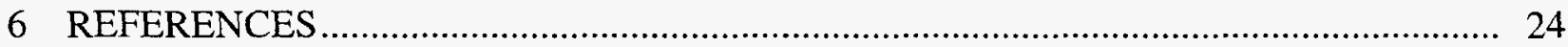

APPENDIX: Parameters Used to Analyze the Potential Radiation Doses

from Residual Radioactivity at the Heavy Water

Components Test Reactor Site.

\section{FIGURES}

1 Location of the HWCTR Facility, Savannah River Site, Aiken, South Carolina

2 Conceptual Model of Cases A through D for the HWCTR Site: Exposure

Pathways and Location of Residual Radioactivity.

3 RESRAD Results for Case A: Reactor Biological Shield.

4 RESRAD Results for Case B: Contaminated Rubble

5 RESRAD Results for Case C: Contaminated Rubble, Installed Equipment, and Reactor Biological Shield. 


\section{FIGURES (Cont.)}

6 RESRAD Results for Case D: Contaminated Well Cuttings

Excluding Barium-133

7 Case C: Sensitivity Analysis on the Distribution Coefficient of Carbon-14 in the Contaminated Zone

8 Case C: Sensitivity Analysis on the Distribution Coefficient of Carbon-14 in the Unsaturated Zone

9 Case C: Sensitivity Analysis on the Distribution Coefficient of Carbon-14 in the Saturated Zone.

10 Case C: Sensitivity Analysis on the Effective Porosity in the Unsaturated Zone 20

11 Case C: Sensitivity Analysis on the Total Porosity in the Unsaturated Zone 20

\section{TABLES}

1 Radionuclide Concentrations Used in the RESRAD Code for Analysis of the Radiation Dose from Residual Radioactivity at the HWCTR Site

2 Summary of the Potential Maximum Dose Rates for Cases A, B, C, and D from Residual Radioactivity at the HWCTR Site

A.1 Parameters Used in the RESRAD Computer Code to Analyze the Potential Radiation Doses from Residual Radioactivity at the HWCTR Site 


\section{NOTATION}

The following is a list of the acronyms, initialisms, and abbreviations (including units of measure) used in this document. Acronyms used only in tables are defined in the respective tables.

\section{ACRONYMS, INITIALISMS, AND ABBREVIATIONS}

DOE U.S. Department of Energy

HWCTR Heavy Water Components Test Reactor

RESRAD residual radioactive material guidelines (computer code)

SRS Savannah River Site

\section{CHEMICALS AND ELEMENTS}

Ac actinium

Am americium

$\mathrm{Ba}$ barium

C carbon

Co cobalt

Cs cesium

$\mathrm{Eu}$ europium

$\mathrm{Gd}$ gadolinium

$\mathrm{H}-3$ tritium

$\mathrm{Ni}$ nickel

\section{UNITS OF MEASURE}

$\begin{array}{ll}\mathrm{cm}^{3} & \text { centimeter(s) } \\ \mathrm{cm}^{3} & \text { cubic centimeter(s) } \\ \mathrm{d} & \text { day(s) } \\ \mathrm{g} & \text { gram(s) } \\ \mathrm{h} & \text { hour(s) } \\ \mathrm{kg} & \text { kilogram(s) } \\ \mathrm{km} & \text { kilometer(s) } \\ \mathrm{km}^{2} & \text { square kilometer(s) } \\ \mathrm{L} & \text { liter(s) } \\ \mathrm{m} & \text { meter(s) }\end{array}$

$\mathrm{m}^{2}$

$\mathrm{m}^{3}$

mrem

MW-d

MWt

$\mathrm{pCi}$

$\mathrm{s}$

ton

yr

$\mathrm{Np}$ neptunium

$\mathrm{Pa}$ protactinium

$\mathrm{Pb}$ lead

$\mathrm{Pu}$ plutonium

$\mathrm{Ra}$ radium

$\mathrm{Rn}$ radon

$\mathrm{Sr}$ strontium

Th thorium

U uranium

$\begin{array}{ll}\mathrm{m}^{2} & \text { square meter(s) } \\ \mathrm{m}^{3} & \text { cubic meter(s) } \\ \text { mrem } & \text { millirem } \\ \mathrm{MW}-\mathrm{d} & \text { megawatt-day(s) } \\ \mathrm{MWt} & \text { megawatt(s) (thermal) } \\ \mathrm{pCi} & \text { picocurie(s) } \\ & \text { second(s) } \\ \text { ton } & \text { ton (short) } \\ \mathrm{yr} & \text { year(s) }\end{array}$




\title{
RADIOLOGICAL DOSE ASSESSMENT FOR THE DISMANTLEMENT AND DECOMMISSIONING OPTION FOR THE HEAVY WATER COMPONENTS TEST REACTOR FACILITY AT THE SAVANNAH RIVER SITE, AIKEN, SOUTH CAROLINA
}

\author{
by \\ E.R. Faillace, S. Kamboj, C. Yu, and S.-Y. Chen
}

\begin{abstract}
Potential maximum radiation dose rates over a 10,000-year time horizon were calculated for the dismantlement and decommissioning option for the Heavy Water Components Test Reactor facility at the Savannah River Site, Aiken, South Carolina. The residual radioactive material guidelines (RESRAD) computer code, version 5.781, which implements the methodology described in the U.S. Department of Energy (DOE) manual for establishing residual radioactive material guidelines, was used in this evaluation. This study will help to determine whether it is technically acceptable (in terms of meeting DOE radiation dose limits) for activated and contaminated concrete to remain in the facility, along with embedded radioactive piping and radioactive equipment. Four cases were developed for the land area to evaluate potential future doses; the cases vary with regard to the definitions of the sources. Case A considers the dose from the reactor biological shield; case $\mathrm{B}$ considers the dose from contaminated concrete rubble; case $\mathrm{C}$ considers the dose from the contaminated concrete rubble, the reactor biological shield, and installed equipment; and case $\mathrm{D}$ considers the dose from the contaminated cuttings brought to the surface following the perforation of a well through the contaminated zone in case C. For all four cases, groundwater drawn from a well located at the downgradient edge of the contaminated land is the only source of water for drinking, irrigation, and raising livestock. Site-specific parameter values were used to estimate the radiation doses. The results of the evaluation indicate that neither the DOE dose limit of $100 \mathrm{mrem} / \mathrm{yr}$ nor the $15-\mathrm{mrem} / \mathrm{yr}$ dose constraint would be exceeded for any of the cases analyzed. The potential maximum dose rates for cases A, B, C, and D are 0.000028, 0.015, 0.018 , and $0.17 \mathrm{mrem} / \mathrm{yr}$, respectively. The drinking water pathway is the dominant contributor to the doses in cases $\mathrm{A}$ through $\mathrm{C}$, and the external gamma pathway is the dominant contributor in case D. Carbon-14, uranium-234, uranium-238, and americium-241 are the principal radionuclides contributing to the doses in cases A through C. Cobalt-60, europium-152, and barium-133 are the important radionuclides in case D. A sensitivity analysis was performed to determine which parameters have the greatest impact on the estimated doses.
\end{abstract}




\section{INTRODUCTION AND BRIEF HISTORY}

The Savannah River Site (SRS) was built in the early 1950s to produce materials for nuclear weapons. Five large nuclear production reactors were built to produce these materials. The production reactors are no longer in service. Today, the mission of the SRS has shifted to the environmental legacy of the Cold War, with processing for storage or disposal of the radioactive and chemical wastes associated with operation of these reactors and their related facilities. Another prime mission is environmental restoration of the site, which includes projects such as the decommissioning of the Heavy Water Components Test Reactor (HWCTR).

The federally owned SRS reservation is located near Aiken, South Carolina. The U.S. Department of Energy (DOE) Savannah River Operations Office manages the SRS. The Westinghouse Savannah River Company operates the site under contract to DOE.

The SRS occupies an area of approximately $800 \mathrm{~km}^{2}$ in western South Carolina in a mostly rural area of Aiken, Barnwell, and Allendale Counties, about $40 \mathrm{~km}$ southeast of Augusta, Georgia. The Savannah River borders the site on the southwest side. Areas bordering the SRS are chiefly forest and agricultural land. The closest towns to the site are New Ellenton and Jackson, both in South Carolina.

The HWCTR facility is located on approximately $8,094 \mathrm{~m}^{2}$ in the northwest quadrant of the SRS, on property known as U-Area. U-Area lies $4.8 \mathrm{~km}$ from the nearest SRS property boundary and about $4 \mathrm{~km}$ from any major nuclear materials production facilities on the site. Cooled and moderated with pressurized heavy water, this uranium-fueled nuclear reactor was designed to test fuel assemblies for heavy-water power reactors. The HWCTR facility was operated for this purpose from March 1962 to December 1964. The area east of the HWCTR facility is wooded. Adjoining the HWCTR property to the west is the headquarters of the site security force. Other administrative buildings of B-Area are nearby. Figure 1 shows the location of the HWCTR facility on the SRS.

The DOE is undertaking the decommissioning of the HWCTR facility. Many possible alternative approaches have been considered and analyzed (WSRC 1997). Four alternatives studied in detail include (1) dismantlement, in which all radioactive equipment and hazardous contaminants would be removed, the containment dome dismantled, and the property restored to a condition similar to its original preconstruction state; (2) partial dismantlement and interim safe storage, where radioactive equipment, except for the reactor vessel and steam generators, would be removed, along with hazardous materials, and the building sealed, with remote monitoring equipment in place to permit limited inspections at five-year intervals; (3) conversion for beneficial reuse, in which most radioactive equipment and hazardous materials would be removed and the containment building converted to another use, such as a storage facility for radioactive materials; and (4) entombment, which involves removing hazardous materials, filling the belowground structure with concrete, removing the containment dome, and pouring a concrete cap on the "tomb." Among these alternatives, dismantlement remains the DOE preferred alternative. As an input to the cost-benefit analysis, potential exposure from radiation 


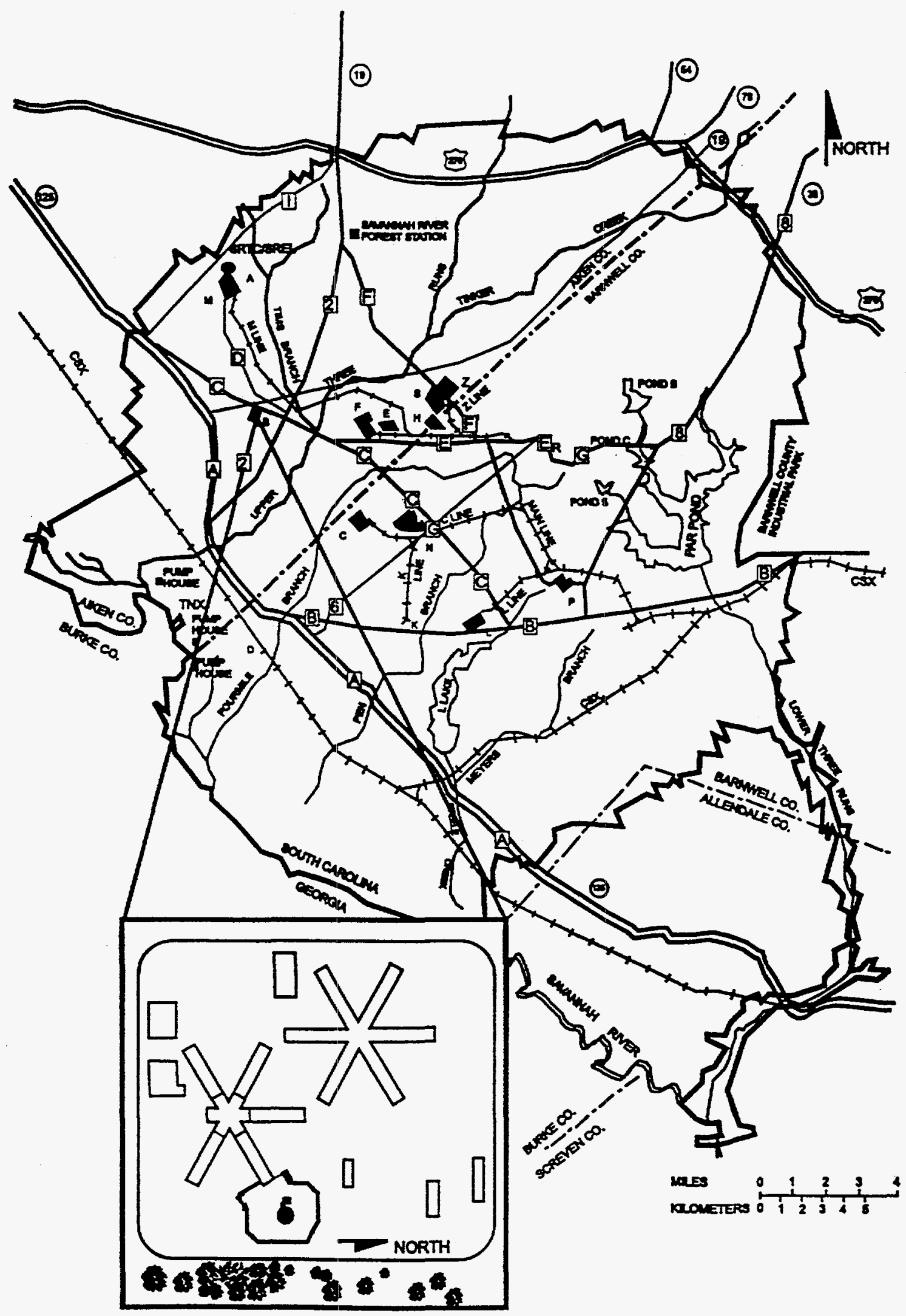

FIGURE 1 Location of the HWCTR Facility, Savannah River Site, Aiken, South Carolina (Source: WSRC 1997) 
has been analyzed with the residual radioactive material guidelines (RESRAD) computer code. This study will help to determine whether it is technically acceptable (in terms of meeting DOE radiation dose limits) for activated and contaminated concrete to remain in the facility, along with embedded radioactive piping and radioactive equipment.

For this project, the DOE plans to use the release criteria of DOE Order 5400.5 (DOE 1990). These criteria require that exposure to members of the public from residual radioactivity be less than $100 \mathrm{mrem} / \mathrm{yr}$ from all exposure pathways and as low as reasonably achievable below this value. To allow for the contribution from other sources of radiation, an additional dose constraint of $30 \mathrm{mrem} / \mathrm{yr}$ is imposed on radiation exposures contributed by residual radioactivity from the HWCTR facility.

The RESRAD computer code, version 5.781, which implements the methodology described in the DOE manual for establishing residual radioactive material guidelines ( $\mathrm{Yu}$ et al. 1993), was used to perform a dose assessment for the residual radioactivity at the HWCTR site.

\subsection{SITE DESCRIPTION AND SETTING}

The HWCTR was a pressurized heavy-water test reactor $(50 \mathrm{MWt})$ used to test candidate fuel designs for heavy-water power reactors. The HWCTR was not a defense-related facility like the material production reactors on the site. The reactor is housed in a steel-domed containment building. The lower part of this building is made of reinforced concrete and extends approximately $18.7 \mathrm{~m}$ below ground level. The containment building is $21.3 \mathrm{~m}$ in diameter. The structure rises approximately $19.8 \mathrm{~m}$ above the ground; the floor of the lowest level is approximately $15.8 \mathrm{~m}$ below grade (WSRC 1997). The dome shell contains approximately 170 tons of steel. The 98-ton steel reactor vessel, the reactor biological shield, two steam generators, and related process equipment reside underground. The containment building also houses the coolant systems, the refueling machine, the spent-fuel basin, and the reactor instrumentation.

The reactor core consisted of a central region of 12 test assemblies surrounded by a ring of 24 driver fuel assemblies, enriched in uranium-235. The reactor vessel has an overall height of $9.1 \mathrm{~m}$ and a diameter of about $2.4 \mathrm{~m}$ and weighs approximately 100 tons. Components in the main circulating system include two steam generators, nine pumps, two gas recompressors, a filter, a deionizer, and a large main storage tank.

In addition to the containment building, the following HWCTR structures form part of the facility: (1) the health physics building (735-U); (2) the ventilation exhaust stack (791-U); (3) the deluge control bunker (788-B); and (4) Building 704-B.

\subsection{SITE HISTORY}

The HWCTR facility was operated from March 1962 to December 1964 to test fuel elements and other reactor components of potential use in heavy-water-moderated and -cooled 
power reactors. The total power history of the HWCTR facility was 13,882 MW-d. During operations, 36 different fuel assemblies were tested. Ten of these experienced cladding failures as the operational capabilities of the different assemblies were being established.

The fuel assembly failures released fission products, uranium, and transuranic radionuclides into the main cooling system and the isolated liquid loop. Even though the boiling loop was never used to test fuel assemblies, it, too, became contaminated with radioactivity as a result of a leak that developed in the "bayonet" fixture designed to isolate a test element in this system from the rest of the reactor vessel.

During the entire operating period, the steam generators leaked heavy water into the steam system, which caused that system to become radioactively contaminated. The total heavywater loss from the plant during operation amounted to approximately $9,980 \mathrm{~kg}$, approximately one-third of which entered the steam system through the steam generators. Spills of radioactive heavy water occurred frequently in most areas of the reactor building during the operating period.

In December 1964, operations were terminated, and the facility was placed in a standby condition as a result of the decision made by the U.S. Atomic Energy Commission to redirect research-and-development work on heavy-water reactors to reactors cooled with organic materials. For about one year, site personnel maintained the facility in a standby status and then retired the reactor in place.

After the final shutdown in December 1964, all of the fuel assemblies and the two neutron sources were removed from the reactor and transported to the Receiving Basin for OffSite Fuel located in H-Area at the SRS. All other reactor components, including control and safety rods, long-term corrosion coupons, and a rod containing gamma ion chambers, were left in the core, as were all housings and guide tubes.

Very few changes have been made in the HWCTR systems since shutdown. Some equipment has been removed, such as the boiling loop surge tank and heat exchanger. In general, radiation levels have decayed to low values (less than $1 \mathrm{mrem} / \mathrm{h}$ ), with only a few hot spots remaining.

\subsection{SUMMARY OF ACTIVITIES}

Since the retirement of the HWCTR facility, it has undergone periodic surveillance. Access has been controlled by the locked security fence surrounding the HWCTR site. Little maintenance has been required since the reactor retirement and the draining of the systems were completed.

Approximately 21 years ago, the U.S. Energy Research and Development Administration made preparations to decommission the HWCTR facility. To support planning for the decommissioning, a characterization study was done in 1975 to determine the location and amounts of radiological contaminants in the facility. The study showed that radiation and 
radioactive contamination levels were low and that most of the radioactivity was contained within the reactor vessel (Field 1976).

A decommissioning plan was developed in 1976, but this plan was never carried out. The condition of the facility for the past 21 years has approximated safe storage or protective confinement. Additional work on the HWCTR decommissioning project began several years ago. In fiscal year 1994, four auxiliary buildings on the HWCTR site were demolished. In 1995 , detailed radiological contamination surveys of the reactor building were performed. These surveys showed that removable contamination levels in the facility were low.

In early 1996, the control building was demolished. During the summer of 1996, a detailed characterization study of the facility was performed (DOE 1996). The characterization study showed that most areas of the facility had radiation levels below $1 \mathrm{mrem} / \mathrm{h}$ and no detectable transferable radioactive contamination. The characterization program included (1) the reactor containment building (Building 770-U); (2) the adjoining health physics building (735-U); (3) the ventilation exhaust stack (791-U); (4) the steam line, stack drain line, and underground tank that lie within the $8,094-\mathrm{m}^{2}$ fenced HWCTR property; and (5) the steam muffler east of the HWCTR property and the underground steam line that leads to it. The characterization program included both radioactive and hazardous contaminants. The characterization work in 1996 included the following elements: (1) direct gamma scan measurements, direct beta-gamma scans, and alpha scans; (2) extensive smear surveys, including inside of the piping systems and the spent-fuel basin; (3) liquid and sediment samples; (4) concrete surface samples from 47 locations; (5) five concrete samples from the reactor biological shield and two from the ground-level floor; and (6) inspection and samples for hazardous materials such as polychlorinated biphenyls, lead, asbestos, and mercury. 


\section{SCENARIO DEFINITIONS}

Four cases in which future on-site individuals could potentially be exposed to residual radioactive material remaining at the HWCTR site were considered. These cases differ only in the definition of the source term and are based on the dismantlement alternative discussed in Section 1. The first three have already been considered by Smith and McNeil (1997); the fourth case is new. For all cases, the assumption is that at some time after 30 years of institutional control, the HWCTR site would be released for use without radiological restrictions. Potential radiation doses resulting from eight exposure pathways were considered: (1) direct exposure to external radiation from residual material; (2) internal radiation from inhalation of potentially contaminated dust; (3) internal radiation from inhalation of emanating radon-222 from the residual material and from household water; (4) internal radiation from ingestion of plant foods grown above the decontaminated area; (5) internal radiation from ingestion of meat from livestock fed with fodder grown above the decontaminated area; (6) internal radiation from ingestion of milk obtained from livestock fed with fodder grown above the decontaminated area; (7) internal radiation from incidental ingestion of residual material; and (8) internal radiation from drinking water drawn from a downgradient well. The radon inhalation pathway is included only for information; doses for this pathway are subject to separate regulation under DOE Order 5400.5 (DOE 1990). The ingestion of fish from a surface water body located downgradient from the decontaminated area is an additional pathway that is considered in RESRAD. The pond is assumed to be fed by groundwater, not runoff. Because the depth to groundwater is approximately $33 \mathrm{~m}$, the fish ingestion pathway is not considered plausible at the HWCTR site.

All four cases assume subsistence farming use of the decontaminated area. This type of scenario is typically the most restrictive and generally results in the maximum exposure to an individual. The assumption is that at some time in the future, the whole decontaminated area would be transformed into a farm. This land use is considered plausible because of the rural location of the site and the extensive farming land use outside of the boundaries of the SRS. Under this scenario, a hypothetical farmer is assumed in one year to spend $50 \%$ of the time indoors in the decontaminated area, $25 \%$ of the time outdoors in the decontaminated area, and $25 \%$ of the time away from the area ( $\mathrm{Yu}$ et al. 1993). The farmer is assumed to ingest plant foods grown in a garden above the decontaminated area and to ingest meat and milk from livestock that forage on land above the decontaminated area. All water used by the farmer for drinking, household use, irrigation, and livestock watering is from a well located at the downgradient edge of the decontaminated area. The conceptual model for these four cases is shown in Figure 2.

Case A (reactor biological shield) considers only the contribution from the radionuclides present in the activated concrete of the reactor biological shield. Case A does not include the radionuclides from the reactor vessel or the steam generators but does include the radionuclides from the reinforcing steel and piping embedded in the concrete. The reactor biological shield is a 3 -m-tall concrete annular cylinder with inner and outer radii of $1.34 \mathrm{~m}$ and $2.39 \mathrm{~m}$, respectively. The shield, which is currently below grade, is assumed to be buried under $5 \mathrm{~m}$ of soil. 


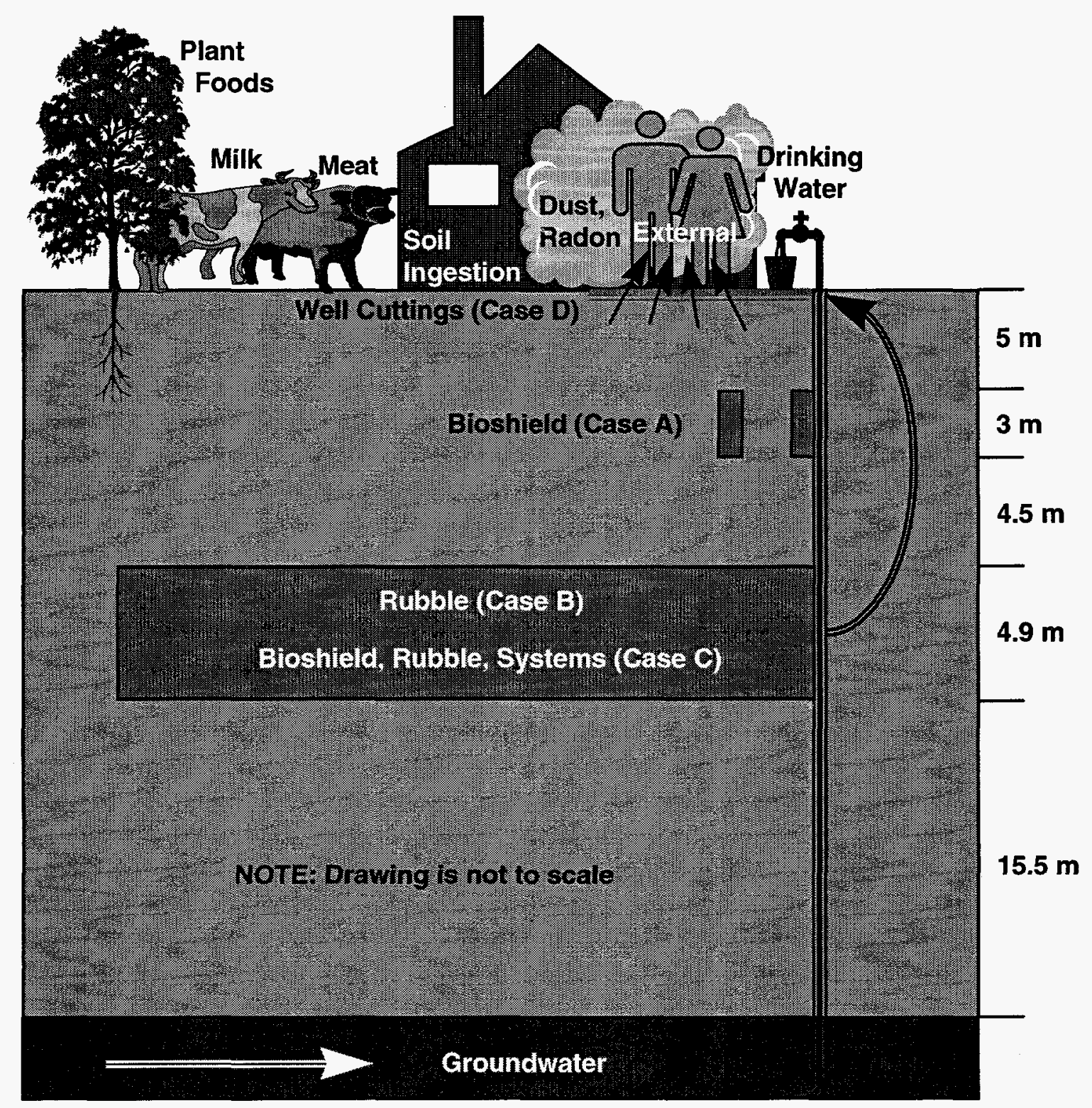

FIGURE 2 Conceptual Model of Cases A through D for the HWCTR Site: Exposure Pathways and Location of Residual Radioactivity

Case B (contaminated rubble) considers the radioactivity in the concrete floors of the facility, including radioactivity inside embedded piping and the spent-fuel basin. These structures are assumed to be demolished, resulting in rubble occupying a cylindrical volume $4.9 \mathrm{~m}$ thick with a $10.5-\mathrm{m}$ radius. The rubble is assumed to be buried under $12.5 \mathrm{~m}$ of soil.

Case C (contaminated rubble, installed equipment, and reactor biological shield) considers the total residual radioactivity in both the contaminated rubble and the reactor biological shield. In addition, this scenario includes the radioactivity associated with all of the installed equipment except the reactor vessel and the steam generators. The source geometry is assumed to be the same as that for case $B$. 
Case D (contaminated well cuttings) considers a new source that would be generated by drilling a well at the downgradient edge of the source considered in case $C$. In the process, some of the contaminated material would be brought up to the surface and is assumed to be spread over the land surface. The soil from the well cuttings is then assumed to be plowed down to $15 \mathrm{~cm}$ below the surface.

The RESRAD computer code, version 5.781 (Yu et al. 1993), was used to calculate the potential radiation doses for the hypothetical subsistence farmer on the basis of the following assumptions:

- During one year, the subsistence farmer spends 4,380 hours (50\%) indoors in the decontaminated area, 2,190 hours $(25 \%)$ outdoors in the decontaminated area, and 2,190 hours (25\%) away from the area (Yu et al. 1993).

- Source parameters, including radionuclide concentrations, dimensions, locations, and geochemical and physical properties, are derived from the report by Smith and McNeil (1997) and its supporting references. These source parameters are discussed in more detail in Section 3.

- To account for the small areas of contamination, the area factor methodology in RESRAD (Yu et al. 1993) is used to estimate the contaminated fraction of the consumed food. Of the plant diet consumed by the subsistence farmer, the contaminated fraction is estimated by the code to be $6.2 \%$ for case A, $17 \%$ for cases B and C, and $10 \%$ for case D.

- The area factor methodology is also used to estimate the contaminated fraction of meat and milk. Of the meat and milk consumed by the subsistence farmer, the contaminated fraction is estimated by the code to be $0.62 \%$ for case $\mathrm{A}, 1.7 \%$ for cases $\mathrm{B}$ and $\mathrm{C}$, and $1 \%$ for case D.

- The source of water for drinking, household uses, irrigation, and livestock watering is assumed to be a local well drilled at the downgradient edge of the contaminated material.

- Site-specific values, derived from the report of Smith and McNeil (1997) and its supporting references, are used for most of the meteorologic parameters, physical and geochemical soil properties, radionuclide distribution coefficients, hydrogeologic conditions, and consumption rates (inhalation and ingestion).

- The remaining parameters are RESRAD defaults. A listing of all of the parameters used in the calculations for each case, as well as a listing of the RESRAD defaults, is provided in the Appendix. 


\section{SOURCE TERMS}

The source term concentrations used in the RESRAD computer code were calculated with data contained in Tables 4 to 6 of Smith and McNeil (1997). Table 1 in the present report gives the residual concentrations used in the RESRAD input for cases A, B, C, and D.

The concentrations for case A (reactor biological shield) were derived by dividing the total activity for each radionuclide listed in Table 4 of Smith and McNeil (1997) by the reported mass of $8.93 \times 10^{7} \mathrm{~g}$. The cross-sectional area of the reactor biological shield was estimated from the inner radius $(1.34 \mathrm{~m})$ and outer radius $(2.39 \mathrm{~m})$. This area of $12.4 \mathrm{~m}^{2}$ is conservatively modeled in RESRAD by assuming the area is a disk with a radius of about $2 \mathrm{~m}$. The height of the reactor biological shield $(3 \mathrm{~m})$ was used as the thickness of the contaminated zone, resulting in a contaminated zone volume of $37 \mathrm{~m}^{3}\left(3.7 \times 10^{7} \mathrm{~cm}^{3}\right)$. The effective density of the reactor biological shield was estimated to be $2.4 \mathrm{~g} / \mathrm{cm}^{3}$. The length parallel to aquifer flow was set to the diameter of the equivalent disk source $(4 \mathrm{~m})$. The cover thickness was set to $5 \mathrm{~m}$, and the thickness of the unsaturated zone below the reactor biological shield was set to $24.9 \mathrm{~m}$.

The concentrations for case B (contaminated rubble) were derived by dividing the total activity for each radionuclide listed in Table 5 of Smith and McNeil (1997) by the reported mass of $2.79 \times 10^{9} \mathrm{~g}$. The cross-sectional area of the contaminated rubble was estimated from the radius of $10.5 \mathrm{~m}$ to be $346 \mathrm{~m}^{2}$. The height of the contaminated rubble, $4.9 \mathrm{~m}$, was used as the thickness of the contaminated zone, resulting in a contaminated zone volume of $1,700 \mathrm{~m}^{3}$ $\left(1.7 \times 10^{9} \mathrm{~cm}^{3}\right)$. The effective density of the contaminated rubble was estimated to be $1.64 \mathrm{~g} / \mathrm{cm}^{3}$. The length parallel to aquifer flow was set to the diameter of $21 \mathrm{~m}$. The cover thickness was set to $12.5 \mathrm{~m}$, and the thickness of the unsaturated zone below the contaminated rubble was set to $15.5 \mathrm{~m}$.

The concentrations for case $\mathrm{C}$ (contaminated rubble, installed equipment, and reactor biological shield) were derived by dividing the total activity for each radionuclide listed in Tables 4 (reactor biological shield), 5 (contaminated rubble), and 6 (installed equipment only) of Smith and McNeil (1997) by the total mass of $2.88 \times 10^{9} \mathrm{~g}$ (reactor biological shield plus contaminated rubble; the mass of the installed equipment is negligible). The reactor biological shield and installed equipment were assumed to be completely incorporated into the contaminated rubble waste volume used for case B. The effective density of this source was estimated to be $1.7 \mathrm{~g} / \mathrm{cm}^{3}$. All other source-related parameters were assumed to be the same as those in case $B$.

In case $\mathrm{D}$ (contaminated well cuttings), a hole $15 \mathrm{~cm}$ in diameter is assumed to be drilled through the entire thickness of the contaminated source in case $\mathrm{C}$, resulting in a contaminated core volume of $8.7 \times 10^{4} \mathrm{~cm}^{3}$. The contaminated well cuttings are assumed to be distributed over an area of $200 \mathrm{~m}^{2}$ and are assumed to be homogeneously mixed with clean soil by plowing, distributing the radionuclides over a $15-\mathrm{cm}$-thick zone. The average density of the newly formed contaminated zone is assumed to be $1.44 \mathrm{~g} / \mathrm{cm}^{3}$. The length parallel to the aquifer flow was assumed to be the square root of the area, or $2.94 \mathrm{~m}$. The cover thickness was set to zero, and the 
TABLE 1 Radionuclide Concentrations Used in the RESRAD Code for Analysis of the Radiation Dose from Residual Radioactivity at the HWCTR Site

Average Radionuclide Concentration ( $\mathrm{pCi} / \mathrm{g}$ )

\begin{tabular}{lccccc} 
& \multicolumn{5}{c}{} \\
\cline { 2 - 6 } Radionuclide & Case A $^{\mathrm{a}}$ & Case B $^{\mathrm{b}}$ & Case C $^{\mathrm{c}}$ & Case C/D $^{\mathrm{d}}$ & Case D $^{\mathrm{e}}$ \\
\hline Am-241 & & & & & \\
Ba-133 & 0.032 & $2.1 \times 10^{-5}$ & 0.14 & 0.13 & 0.00045 \\
$\mathrm{C}-14$ & 1,200 & 0 & 36 & 7.2 & 0.025 \\
Co-60 & 0.0066 & 0.12 & 0.15 & 0.12 & 0.00041 \\
Cs-137 & 7,000 & 0.013 & 220 & 4.1 & 0.014 \\
Eu-152 & 0.013 & 1.6 & 1.6 & 0.80 & 0.0027 \\
Eu-154 & 640 & 0 & 20 & 4.2 & 0.014 \\
H-3 & 40 & 0 & 1.2 & 0.11 & 0.00038 \\
Ni-59 & 19 & 0.20 & 2.0 & 0.25 & 0.00085 \\
Ni-63 & 0.045 & $2.9 \times 10^{-5}$ & 0.20 & 0.20 & 0.00068 \\
Pu-238 & 3.6 & 0.0023 & 16 & 13 & 0.044 \\
Pu-239 & 0.0019 & $2.0 \times 10^{-6}$ & 0.0085 & 0.0067 & $2.3 \times 10^{-5}$ \\
Sr-90 & 0.016 & 0.00018 & 0.068 & 0.068 & 0.00023 \\
U-234 & 0.34 & 0.11 & 1.6 & 0.75 & 0.0025 \\
U-235 & $3.6 \times 10^{-6}$ & 0.0082 & 0.0080 & 0.0079 & $2.7 \times 10^{-5}$ \\
U-238 & 0 & 0.00028 & 0.00027 & 0.00027 & $9.1 \times 10^{-7}$ \\
\hline
\end{tabular}

a Reactor biological shield.

b Contaminated rubble.

c Contaminated rubble, installed equipment, and reactor biological shield.

d Contaminated rubble, installed equipment, and reactor biological shield; after 30-year decay/leaching period.

e Contaminated well cuttings; mixed with clean soil.

$f$ Modeled as Eu-152 (with modified dose factors) with Sr-90 distribution coefficients and transfer factors.

thickness of the unsaturated zone was assumed to be $32.9 \mathrm{~m}$. Because the peak dose would occur at the time when the well is drilled, the erosion rate of this contaminated zone is conservatively set to zero, but the radionuclides are assumed to decay and leach out of the original contaminated zone for 30 years prior to drilling the well (case C/D). The concentrations of radionuclides used as input to RESRAD are adjusted to reflect the mixing with clean soil and the 30-year decay and leaching period. Therefore, the run for case $\mathrm{D}$ is initiated at time zero, rather than at 30 years, as in cases $\mathrm{A}$ through $\mathrm{C}$. For some radionuclides, ingrowth of decay products occurs over the 30-year decay period; however, the concentrations of these decay products are low and do not contribute significantly to the calculated dose. Therefore, their concentrations are not reported in Table 1. The concentrations in case $\mathrm{C}$, rather than those in case $\mathrm{B}$, were used as a starting point 
for case $\mathrm{D}$ because they are slightly more conservative. Case A was not considered a likely starting point because of the smaller source size and the difficulty of drilling a well through a reinforced concrete structure.

The RESRAD code does not include barium-133 in its radionuclide database. Europium-152, with a half-life of 13.5 years, is the gamma-emitting radionuclide in RESRAD that most closely and conservatively approximates the 10.5-year half-life of barium-133. For cases $\mathrm{A}, \mathrm{C}$, and $\mathrm{D}$, separate runs were made by entering the barium-133 concentrations as europium-152 (case B does not include barium-133). In these runs, the inhalation dose conversion factor for europium-152 was changed from $2.21 \times 10^{-4}$ to $5.22 \times 10^{-6} \mathrm{mrem} / \mathrm{pCi}$; similarly, the ingestion dose conversion factor was changed from $6.48 \times 10^{-6}$ to $5.30 \times 10^{-6} \mathrm{mrem} / \mathrm{pCi}$ (Eckerman et al. 1988). Because barium has chemical properties similar to strontium, the soil transfer factors were changed to those used for strontium-90. These changes were incorporated into a special dose factor library named BA-133.BIN. In addition, the distribution coefficients of barium-133 in the contaminated, unsaturated, and saturated zones were set to the strontium-90 distribution coefficient of $10 \mathrm{~cm}^{3} / \mathrm{g}$. The external gamma dose factor for barium-133 is 3.5 times lower than the dose factor for europium-152. Changing the external dose factors for the latter from the user interface is not possible, so the external gamma contribution from barium-133 as europium-152 is adjusted by this factor of 3.5 . 


\section{RESULTS}

The RESRAD computer code, version 5.781, was used to calculate the potential radiation doses for each exposure case. The time frame considered in this analysis was 10,000 years. Radioactive decay and ingrowth were considered in calculating the maximum dose rates. The number of graphic points was increased from the default of 32 to 256 to improve the resolution. The various parameters used in the RESRAD code for this analysis are listed in the Appendix.

\subsection{DETERMINISTIC DOSE ASSESSMENT}

The calculated maximum dose rates for cases A, B, C, and D are presented in Table 2, which also shows the contributions of each pathway to the total dose. For all cases, the maximum dose rate does not exceed the DOE annual limit of $100 \mathrm{mrem} / \mathrm{yr}$ (DOE 1990) or the dose constraint of $30 \mathrm{mrem} / \mathrm{yr}$.

Figure 3 shows the dose rate as a function of time for case A (reactor biological shield). The maximum dose rate of $2.8 \times 10^{-5} \mathrm{mrem} / \mathrm{yr}$ occurs at 470 years after the postdecontamination survey and is due almost entirely to the ingestion of carbon-14 in drinking water. A smaller peak from americium-241 occurs after about 1,500 years.

Figure 4 shows the dose rate as a function of time for case $B$ (contaminated rubble). The maximum dose of $0.015 \mathrm{mrem} / \mathrm{yr}$ occurs at 5,000 years and is due primarily to the ingestion of uranium-234 and uranium-238 in drinking water and vegetables. A slightly smaller peak $(0.014 \mathrm{mrem} / \mathrm{yr})$ occurs at 320 years and is due to the ingestion of carbon-14 in drinking water.

Figure 5 shows the dose rate as a function of time for case $\mathrm{C}$ (contaminated rubble, installed equipment, and reactor biological shield). Carbon-14 in drinking water is again responsible for the maximum dose of $0.018 \mathrm{mrem} / \mathrm{yr}$ at 320 years; the peak dose from the uranium isotopes in drinking water occurs at 5,000 years and contributes $0.015 \mathrm{mrem} / \mathrm{yr}$.

Figure 6 shows the dose rate as a function of time for case $\mathrm{D}$ (contaminated well cuttings) for all radionuclides except barium-133. The well is assumed to be drilled 30 years after the postdecontamination survey. The maximum dose rate of $0.17 \mathrm{mrem} / \mathrm{yr}$ would occur the year when the well is drilled and is due primarily to external gamma from cobalt-60 and europium-152. The barium-133, modeled as europium-152 in a separate run, contributes $0.022 \mathrm{mrem} / \mathrm{yr}$ to the maximum dose rate.

\subsection{PARAMETER SENSITIVITY ANALYSIS}

The previous section indicates that drinking water is the dominant pathway in cases A through $\mathrm{C}$, and external gamma is the dominant pathway in case $\mathrm{D}$. Therefore, the calculated doses will be sensitive to parameters that affect these pathways. 
TABLE 2 Summary of the Potential Maximum Dose Rates for Cases A, B, C, and D from Residual Radioactivity at the HWCTR Site

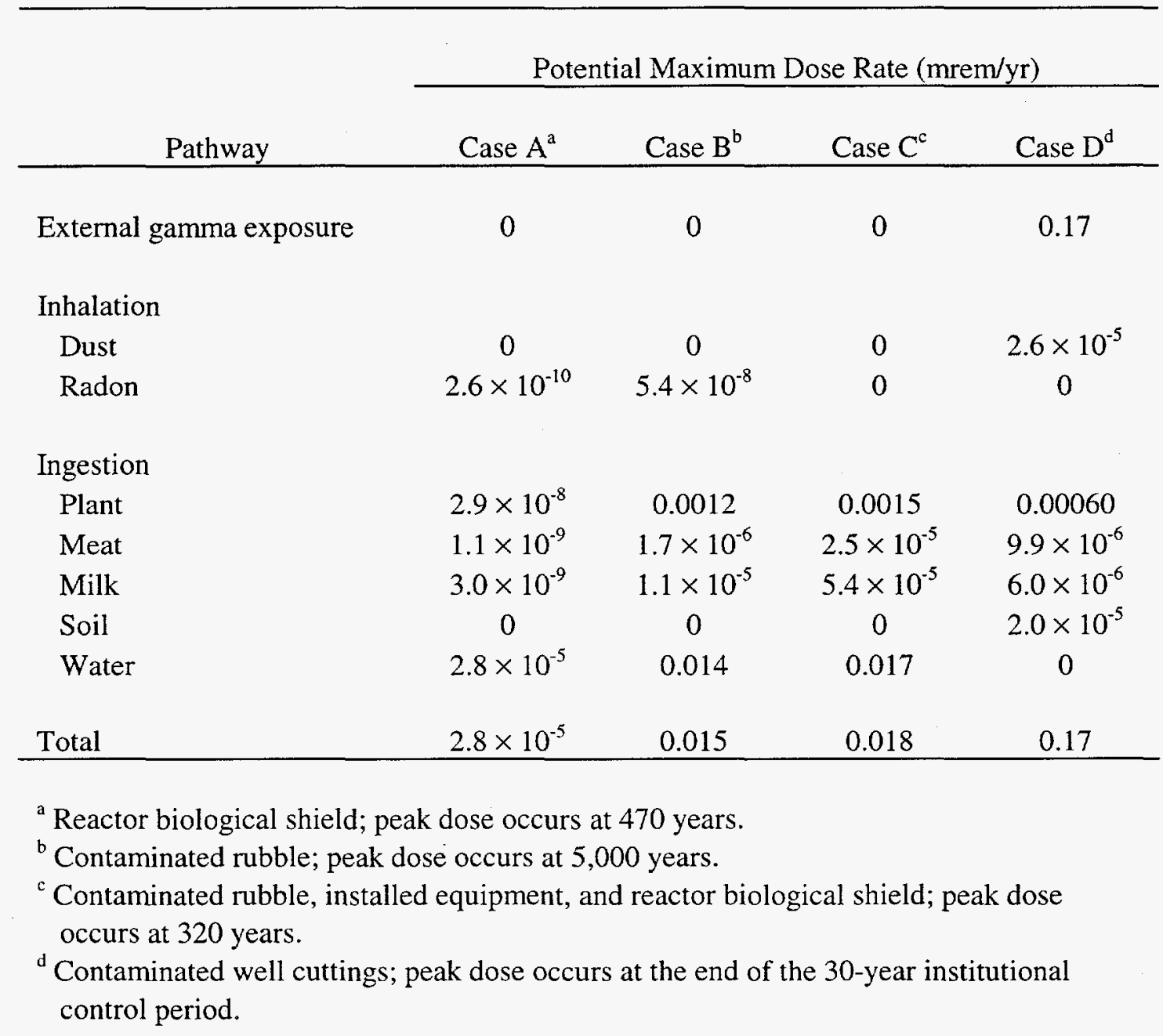

Because the peak dose in case $\mathrm{C}$ is primarily from ingestion of carbon-14 in drinking water, a sensitivity analysis was performed on the distribution coefficient for this radionuclide in the contaminated zone, the unsaturated zone, and the aquifer. The distribution coefficients were set at a factor of 2 higher or lower than the base value of $2 \mathrm{~cm}^{3} / \mathrm{g}$. Figures 7 through 9 show the effect that varying this parameter has on the total dose.

In Figure 7, changing the distribution coefficient in the contaminated zone affects the leach rate of carbon-14. The time at which the peak dose occurs does not change, but the magnitude of the peak dose ranges from about $0.01 \mathrm{mrem} / \mathrm{yr}$ to $0.03 \mathrm{mrem} / \mathrm{yr}$. Note that the higher distribution coefficient for carbon-14 in the contaminated zone would result in the peak dose actually occurring at 5,000 years, caused by the uranium isotopes. 


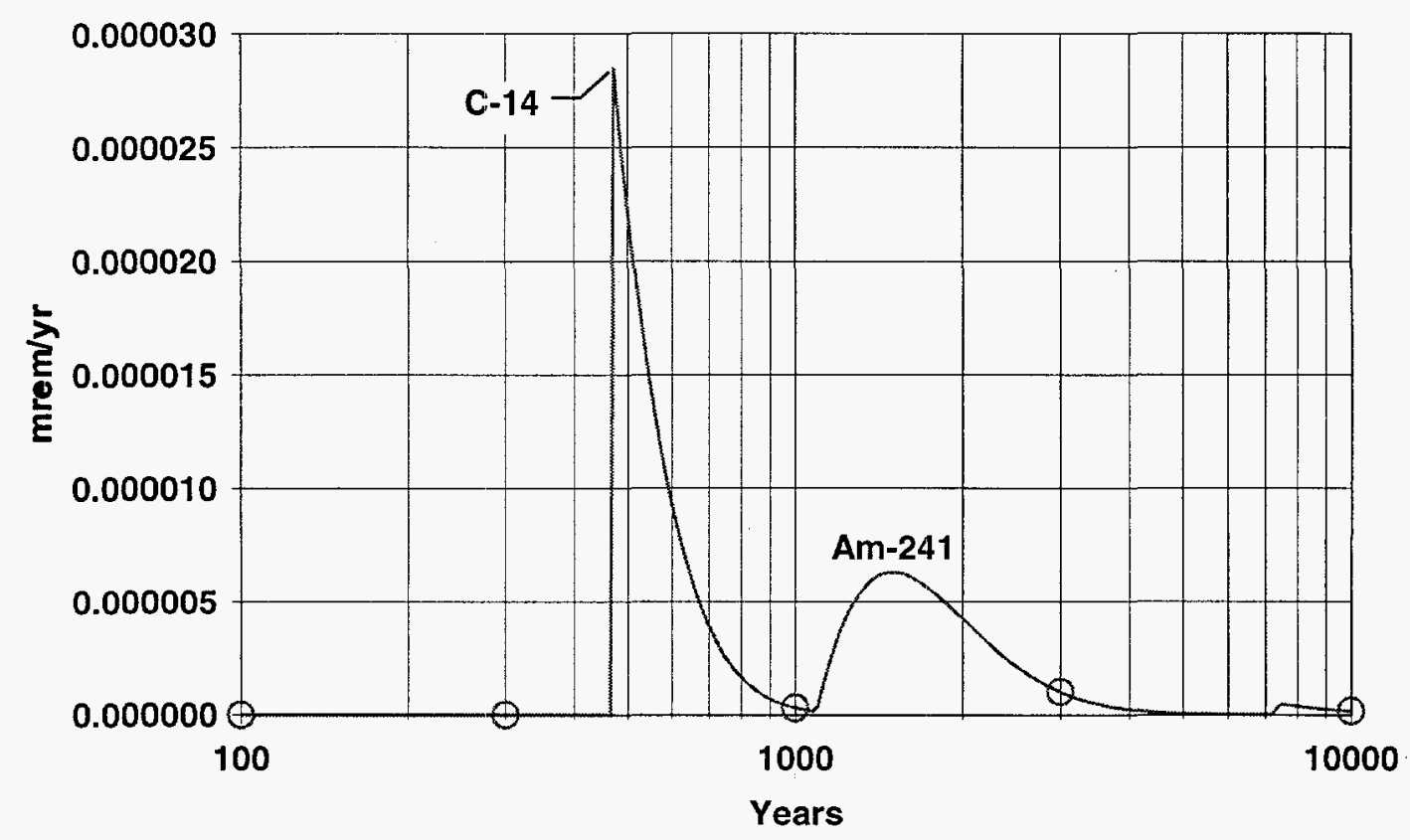

FIGURE 3 RESRAD Results for Case A: Reactor Biological Shield

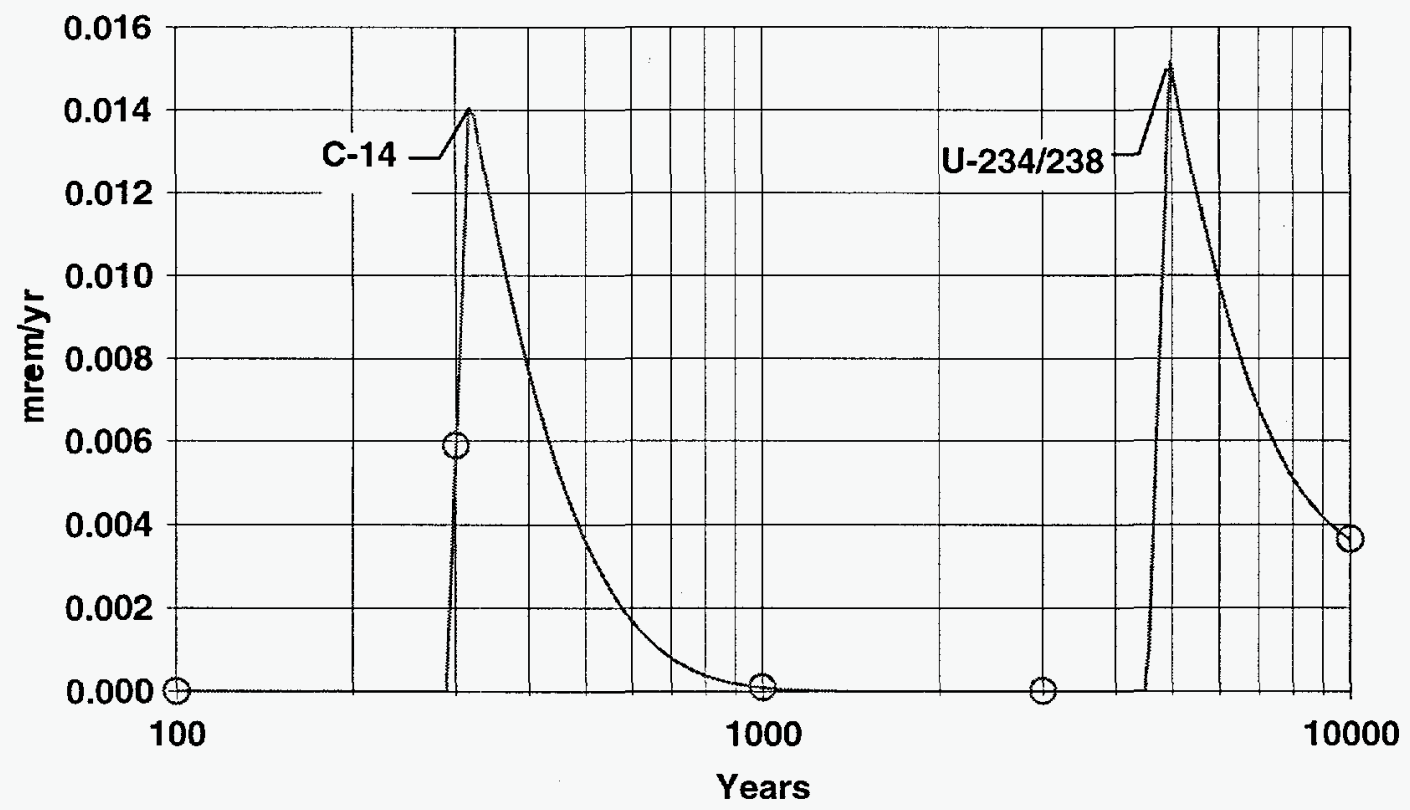

FIGURE 4 RESRAD Results for Case B: Contaminated Rubble 


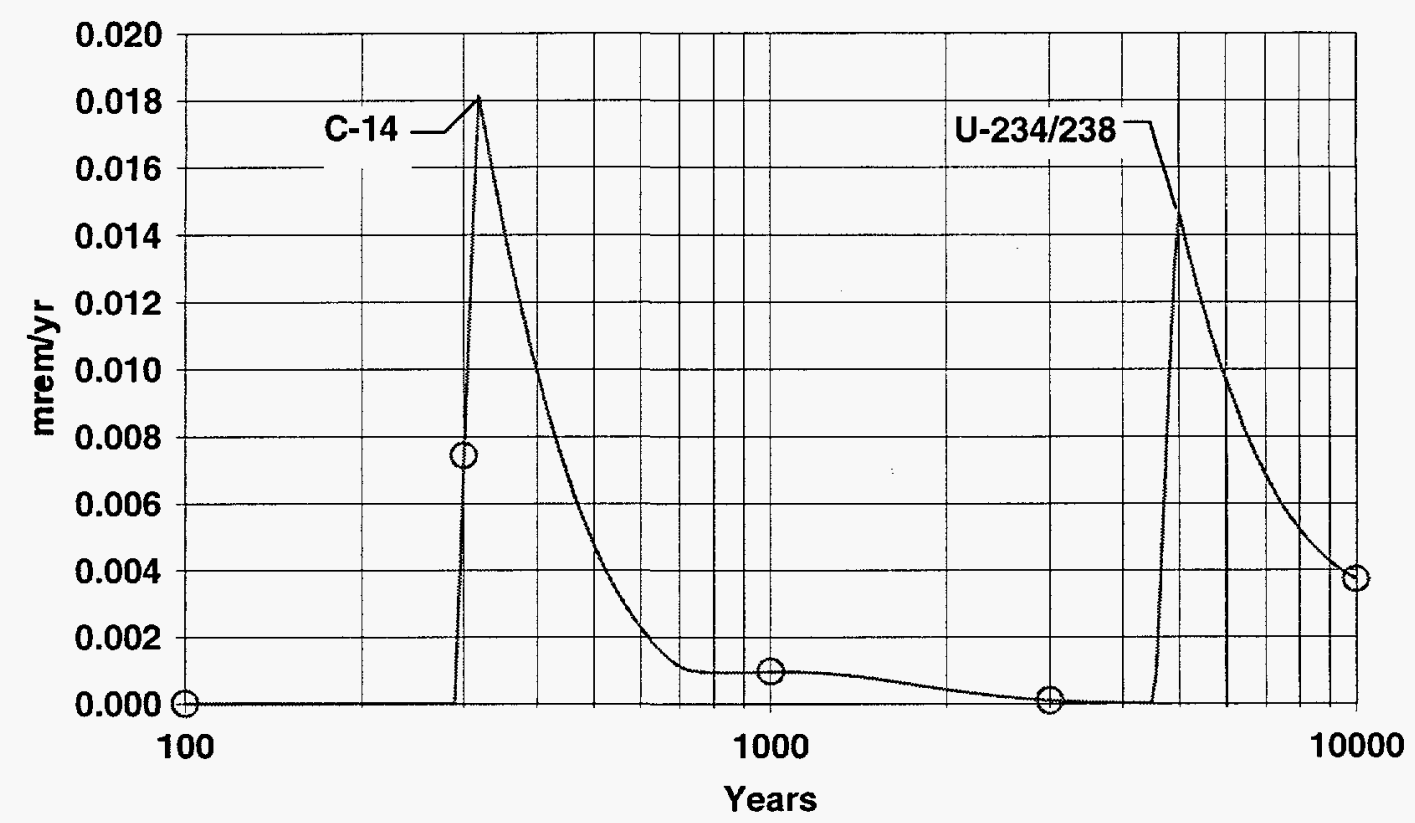

FIGURE 5 RESRAD Results for Case C: Contaminated Rubble, Installed Equipment, and Reactor Biological Shield

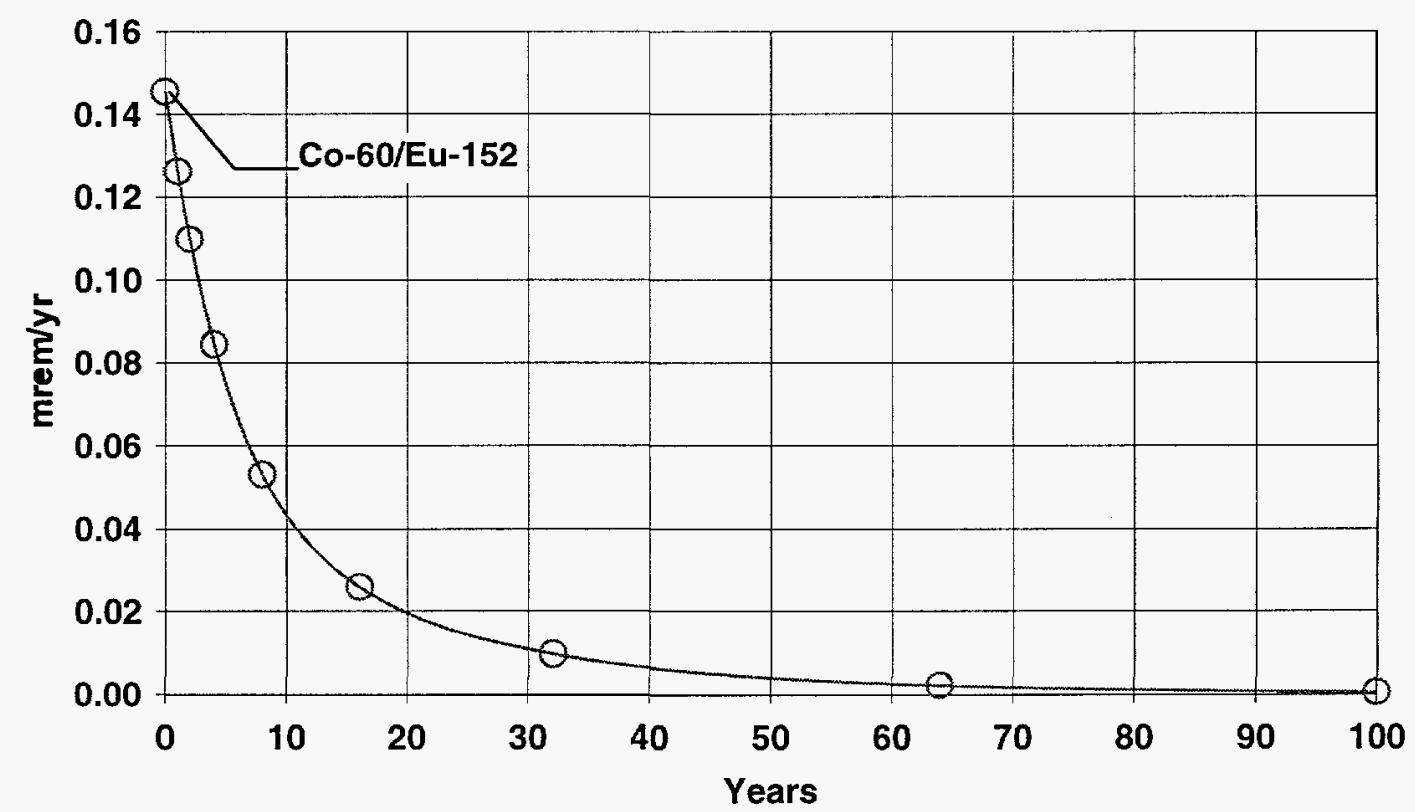

FIGURE 6 RESRAD Results for Case D: Contaminated Well Cuttings Excluding Barium-133 


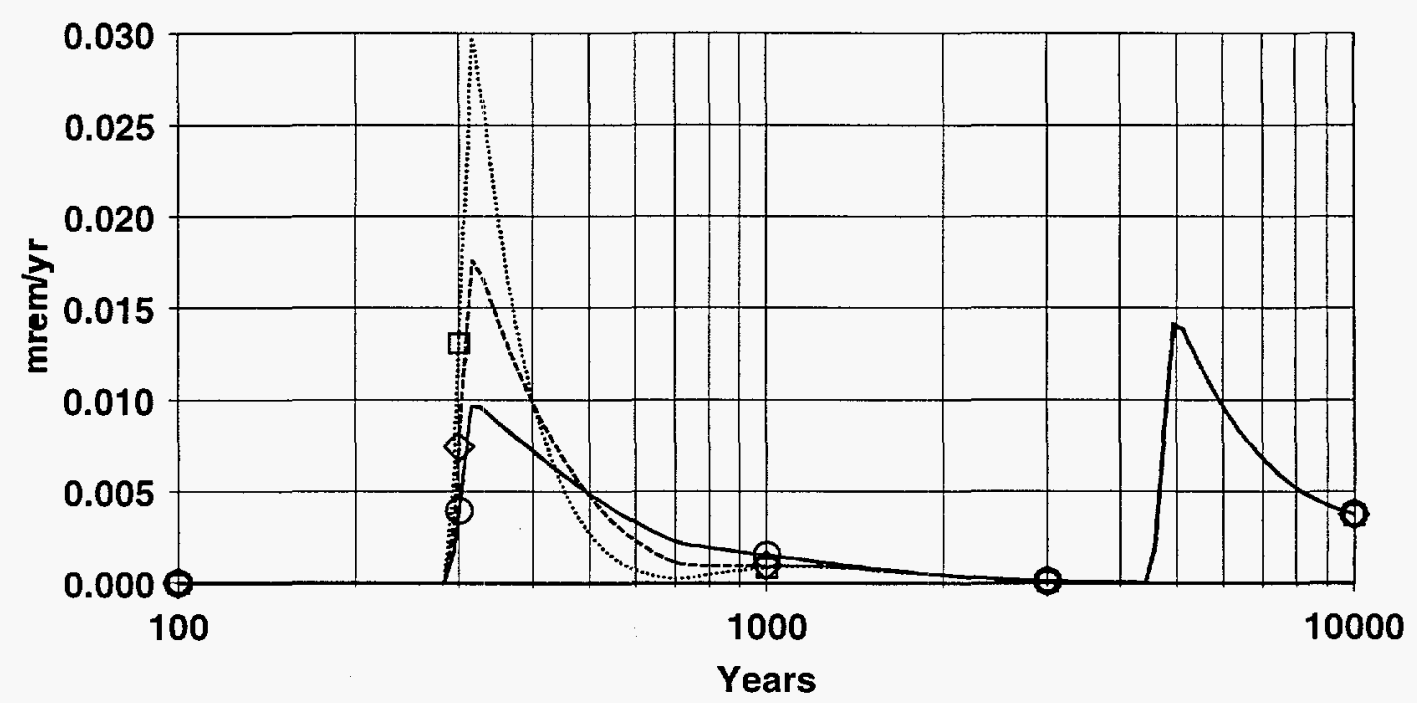

$\Theta$ Upper: $4-\Theta$ - Mid: $2 \quad$ …… Lower: 1

FIGURE 7 Case C: Sensitivity Analysis on the Distribution Coefficient of Carbon-14 in the Contaminated Zone

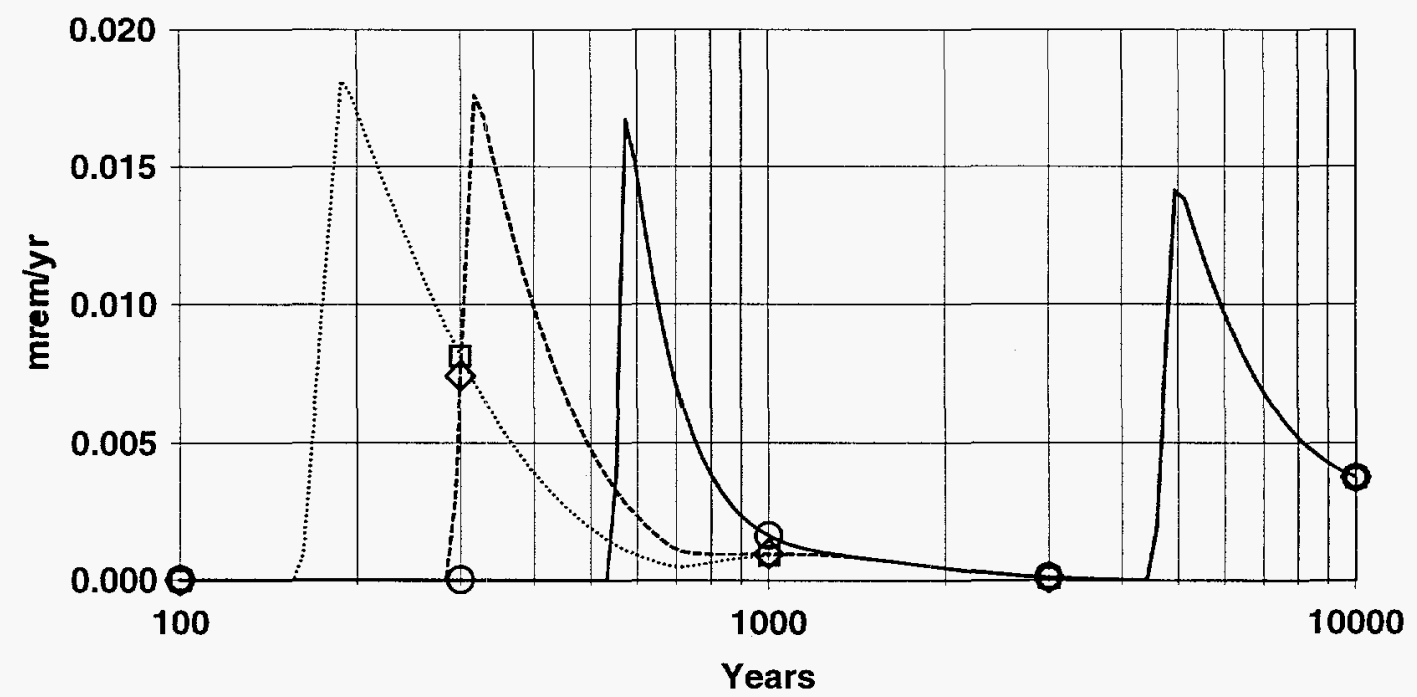

$\Theta$ Upper: $4 \quad-\Theta$ - Mid: $2 \quad \cdots \boxminus$ Lower: 1

FIGURE 8 Case C: Sensitivity Analysis on the Distribution Coefficient of Carbon-14 in the Unsaturated Zone 
In Figure 8, changing the distribution coefficient in the unsaturated zone affects the transport time of carbon-14 through this zone. A lower distribution coefficient would result in a peak dose occurring sooner in time but would not increase the magnitude of the peak dose significantly. Increasing the distribution coefficient has the effect of delaying the occurrence of the peak.

Figure 9 shows that changing the distribution coefficient in the aquifer does not have much of an impact on the dose from carbon-14. A lower distribution coefficient results in a sharper peak and a slightly higher dose. Increasing the distribution coefficient has the opposite effect.

Variations in the distribution coefficient of the uranium isotopes would have similar results but would affect the second peak. Because the magnitudes of the carbon-14 and uranium peaks are very close, it is possible that the uranium dose may be higher than the carbon-14 dose if the uranium distribution coefficient in the contaminated zone is lower than the estimated value.

A sensitivity analysis was also performed on the hydrogeologic parameters that affect the contaminated, unsaturated, and saturated zones. Of these parameters, only variations in the effective and total porosity of the unsaturated zone had significant impacts on the dose calculations. Figures 10 and 11 show the sensitivity of the dose to changes of $25 \%$ higher or lower than the base value of effective and total porosity, respectively. Figure 10 shows that increasing the effective porosity delays the time at which the peak dose occurs. Figure 11 shows that the opposite is true for increases in the total porosity. Because the effective porosity is

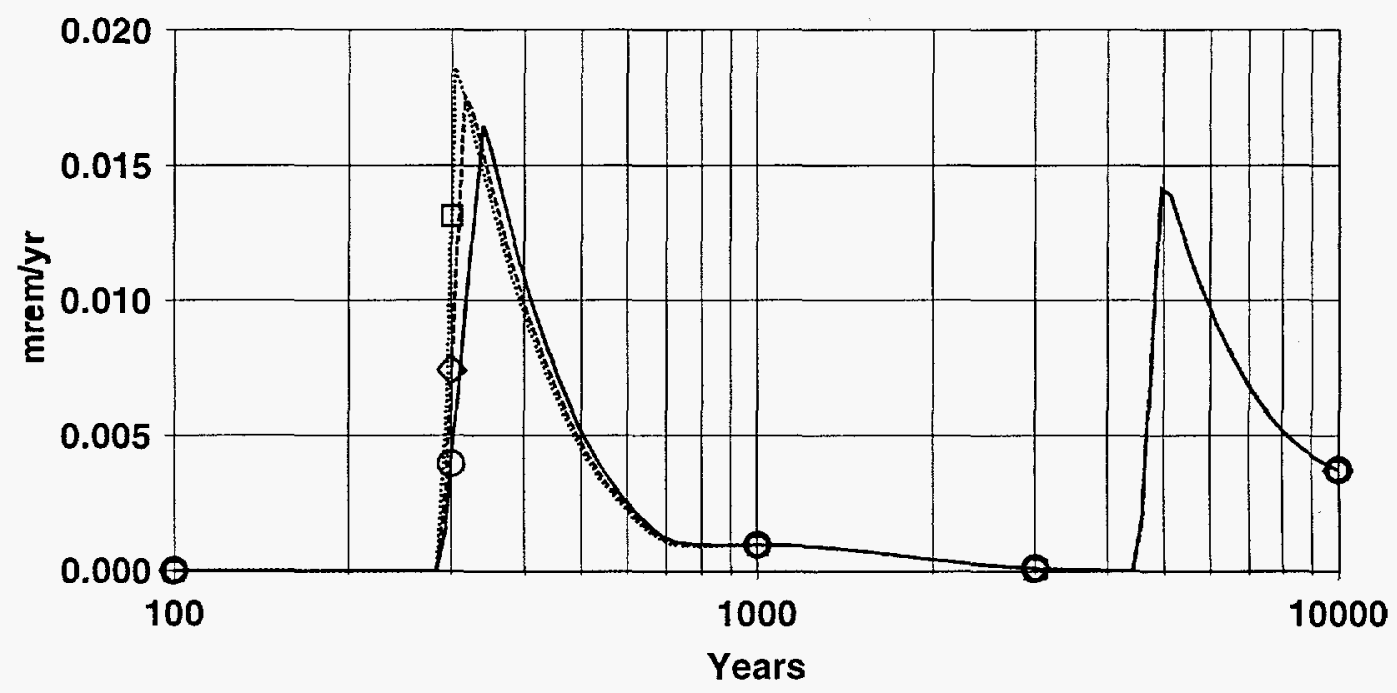

- Upper: $4 \quad-\Theta$ - Mid: $2 \quad \cdots \boxminus$ L... Lower: 1

FIGURE 9 Case C: Sensitivity Analysis on the Distribution Coefficient of Carbon-14 in the Saturated Zone 


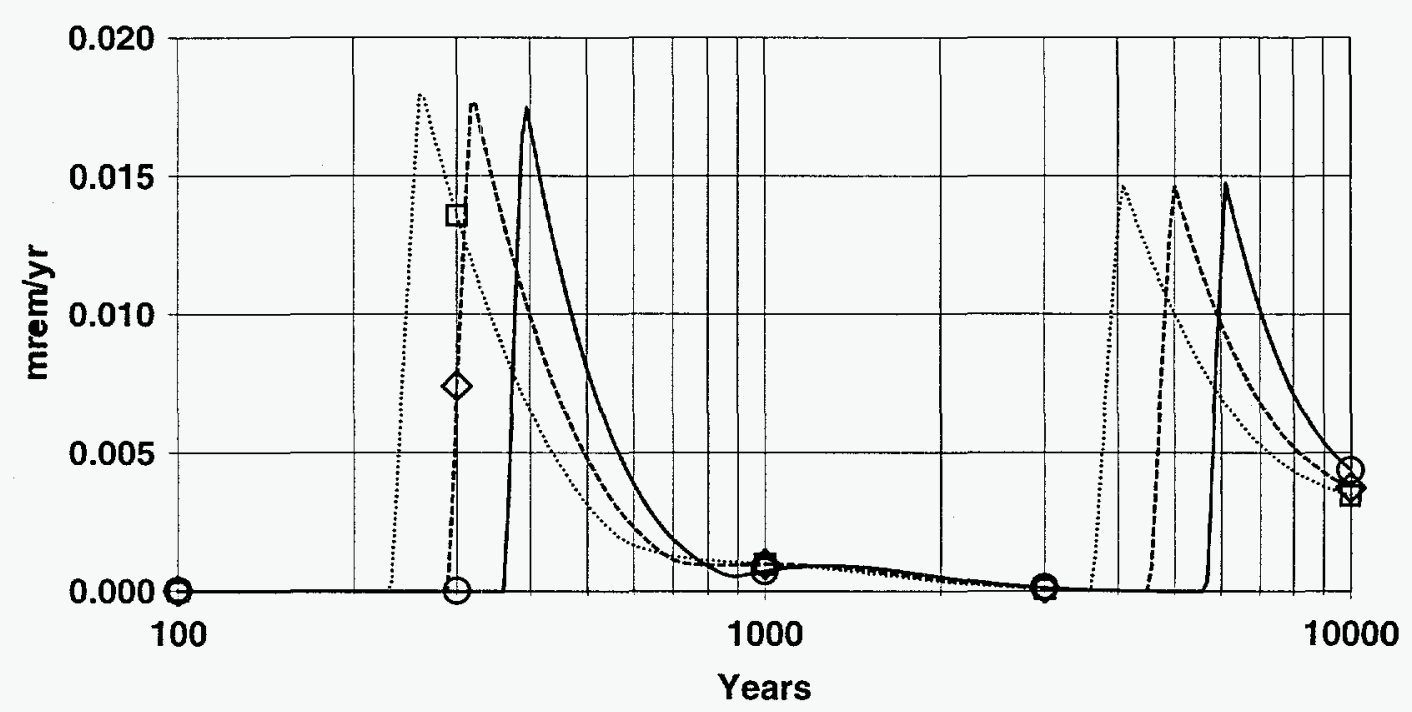

$\bigoplus$ Upper: .4125 $-\Theta$ Mid: .33 …… Lower: .264

FIGURE 10 Case C: Sensitivity Analysis on the Effective Porosity in the Unsaturated Zone

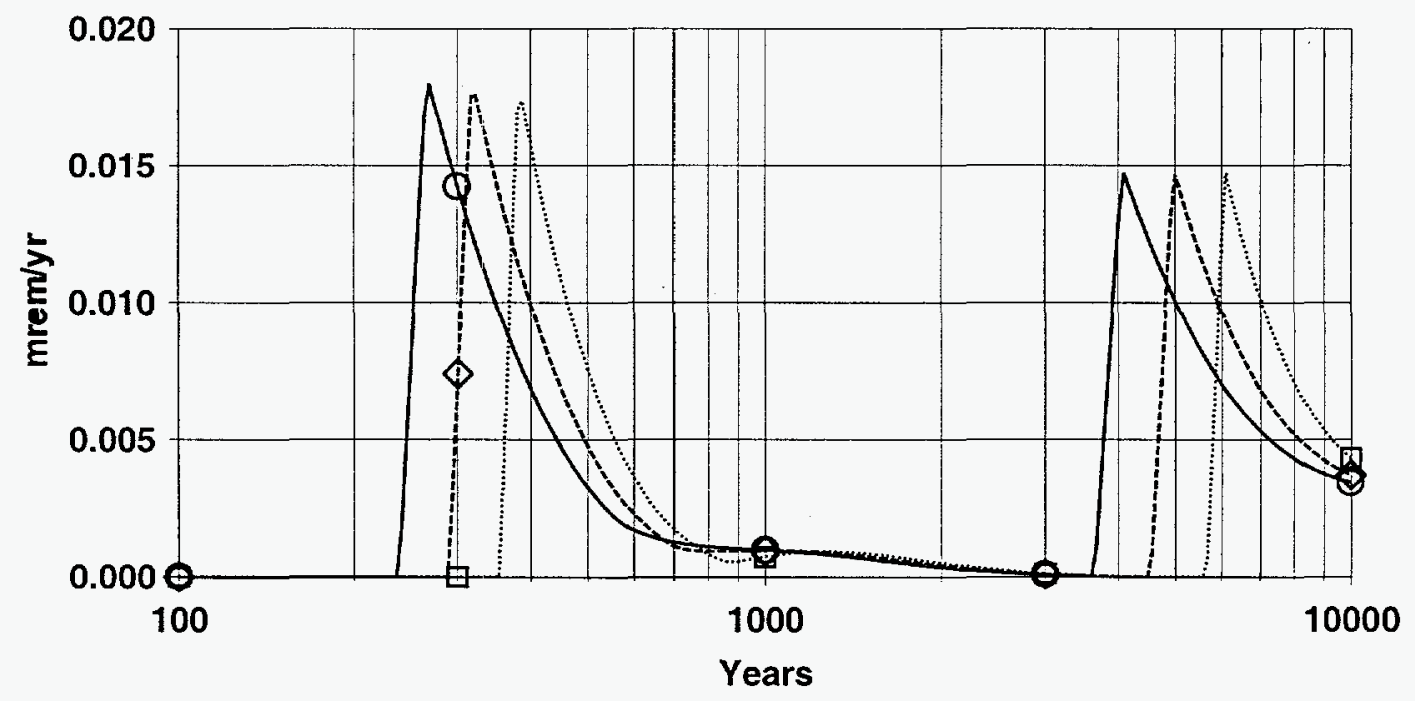

$\bigoplus$ Upper: $.5375 \quad-\Theta$ - Mid: $.43 \quad \cdots \boxminus \cdots$ Lower: .344

FIGURE 11 Case C: Sensitivity Analysis on the Total Porosity in the Unsaturated Zone 
always equal to or less than the total porosity, these two parameters are correlated. Therefore, the net sensitivity of the dose to variations in these parameters would be less than if they were independent of each other.

Other parameters that affect the drinking water pathway are the water ingestion rate and the infiltration rate. The dose will be directly proportional to the consumption of drinking water. The infiltration rate is a function of the precipitation rate, irrigation rate, runoff coefficient, and evapotranspiration rate. Variations in the infiltration rate would result in shifts in the time at which the peak dose occurs but would not have a significant effect on the magnitude of the peak dose.

In case $\mathrm{D}$, the assumption was that the contaminated well cuttings would be spread over $200 \mathrm{~m}^{2}$ and then mixed with uncontaminated soil to a depth of $15 \mathrm{~cm}$. A sensitivity analysis was performed to determine what the effect would be if the well cuttings were not mixed with uncontaminated soil. The concentrations listed under case $\mathrm{C} / \mathrm{D}$ in Table 1 were used along with a 1 -cm-thick source spread out over $8.7 \mathrm{~m}^{2}$, resulting in a dose of $2.3 \mathrm{mrem} / \mathrm{yr}$. Other factors that would affect the external gamma dose would be the time spent at the site and the credit taken for shielding while the individual is indoors. Radionuclide concentrations in the well cuttings depend on the amounts of leaching and radioactive decay from the buried source that occur over 30 years. Therefore, the dose will be sensitive to parameters that affect the leach rates, such as distribution coefficients and the infiltration rate. 


\section{COMPARISON WITH RESULTS OF SMITH AND MCNEIL (1997)}

The results of the dose assessment performed for this report are compared with the results reported by Smith and McNeil (1997). The latter were derived by using RESRAD, version 5.621. Cases A through $\mathrm{C}$ in this report are equivalent to scenario A (subsistence farmer; three source configurations) in the report by Smith and McNeil (1997); case D was not modeled by the latter. Figures 10 through 12 of Smith and McNeil (1997) correspond to Figures 3 through 5 in this report.

For case A, the present dose assessment yields essentially the same results as those obtained by Smith and McNeil (1997). For cases B and C, the present dose assessment yields results for the uranium peak doses that are less than half of those obtained by Smith and McNeil (1997) but are only slightly lower for carbon-14. The reasons for these differences are outlined in the following paragraphs.

The differences between the two versions of RESRAD (version 5.621 and version 5.781) contribute very little to the differences in the two sets of results. The pathway that would be impacted most is the inhalation pathway because of changes in the area factor methodology and a reduction in the default value used for mass loading; the current version of RESRAD would yield lower inhalation doses than version 5.621. The primary pathway contributing to dose in cases A to $C$ is the drinking water pathway, but the model for this pathway is the same in both versions of the code. Another difference between the two versions of the RESRAD code is that the user now has access in the plant pathway to additional parameters that were once fixed. This change does not impact the results because the defaults for these parameters are used in the calculations.

One major change in the input parameters is responsible for most of the difference in the results. Smith and McNeil (1997) entered the density of the rubble source term (case B in this report) and modified source term (case C) as $2.4 \mathrm{~g} / \mathrm{cm}^{3}$, when it should have been entered as $1.6 \mathrm{~g} / \mathrm{cm}^{3}\left(1.64 \mathrm{~g} / \mathrm{cm}^{3}\right.$ was used in the present assessment for case B). Their entry had the effect of increasing the inventory of radionuclides in the source. Minor factors are the failure to include the bioshield mass in the modified source term. Including this mass but keeping the source geometry constant requires a slightly higher density $\left(1.7 \mathrm{~g} / \mathrm{cm}^{3}\right.$ was used in the present assessment for case $\mathrm{C}$ ). Another factor is the discrepancy between the concentrations calculated by Smith and McNeil (1997) for tritium, cobalt-60, and uranium-238 in the rubble source term and the modified source term.

Other differences in the input values that did not have significant impacts on the calculations are as follows:

- The area factor methodology was used for the plant, meat, and milk pathways in the present assessment, whereas a contamination fraction of 50\% was used by Smith and McNeil (1997). The area factor takes into account the small size of the contaminated zone but does not significantly impact the dose calculations because the drinking water pathway is the dominant contributor to the dose. 
- Separate runs were made for barium-133 as europium-152, rather than combining the concentrations of these two radionuclides under europium-152, as was done by Smith and McNeil (1997). This factor did not significantly impact the dose in cases $\mathrm{A}$ through $\mathrm{C}$ because neither of these two radionuclides contributes much to the dose in these cases; however, combining the concentrations of these two radionuclides would have a significant impact in case $\mathrm{D}$ because one of the largest contributors to the dose is europium-152. Although barium-133 has a higher concentration than europium-152, the smaller distribution coefficient of the former results in a significant amount of barium that would leach out of the contaminated zone over the 30-year institutional control period. In addition, the two radionuclides have external gamma dose factors that differ by a factor of 3.5 . 


\section{REFERENCES}

DOE: see U.S. Department of Energy.

Eckerman, K.F., et al., 1988, Limiting Values of Radionuclide Intake and Air Concentration and Dose Conversion Factors for Inhalation, Submersion and Ingestion, EPA-520/1-88-020, Federal Guidance Report No. 11, prepared by Oak Ridge National Laboratory, Oak Ridge, Tenn., for the U.S. Environmental Protection Agency, Office of Radiation Programs, Washington, D.C.

Field, F.R., 1976, A Decommissioning Plan for the Heavy Water Components Test Reactor, DPST-75-417, U.S. Energy Research and Development Administration, DuPont Savannah River Plant, Jan.

Smith, R., and J. McNeil, 1997, Residual Radioactivity Guidelines for the Heavy Water Components Test Reactor at the Savannah River Site, Westinghouse Savannah River Company, Aiken, S.C., April.

U.S. Department of Energy, 1990, "Radiation Protection of the Public and the Environment," Order 5400.5, Washington, D.C., Feb. 8.

U.S. Department of Energy, 1996, Facility Characterization Report for the Heavy Water Components Test Reactor at the Savannah River Site, Sept.

Westinghouse Savannah River Company, 1997, Analysis of Removal Alternatives for the Heavy Water Components Test Reactor at the Savannah River Site, WSRC-TR-96-0268, Rev. 1, Aiken, S.C., April.

WSRC: see Westinghouse Savannah River Company.

Yu, C., et al., 1993, Manual for Implementing Residual Radioactive Material Guidelines Using RESRAD, Version 5.0, ANL/EAD/LD-2, Argonne National Laboratory, Environmental Assessment Division, Argonne, Ill., Sept. 


\section{APPENDIX:}

PARAMETERS USED TO ANALYZE THE POTENTIAL RADIATION DOSES FROM RESIDUAL RADIOACTIVITY AT THE HEAVY WATER COMPONENTS TEST REACTOR SITE 


\section{APPENDIX:}

\section{PARAMETERS USED TO ANALYZE THE POTENTIAL RADIATION DOSES FROM RESIDUAL RADIOACTIVITY AT THE HEAVY WATER COMPONENTS TEST REACTOR SITE}

The parametric values used in the residual radioactive material guidelines (RESRAD) computer code for the analysis of the radiation doses following the decommissioning of the Heavy Water Components Test Reactor (HWCTR) facility are listed in Table A.1 for each of the four cases considered. All parametric values are reported up to three significant figures. Some values are specific to the site (Smith and McNeil 1997); others are RESRAD defaults (Yu et al. 1993).

All four cases assume subsistence farming use of the decontaminated area. The assumption is that at some time in the future, the whole decontaminated area would be transformed into a farm. Under this scenario, a hypothetical farmer is assumed in one year to spend $50 \%$ of the time indoors in the decontaminated area, $25 \%$ of the time outdoors in the decontaminated area, and $25 \%$ of the time away from the area. The farmer is assumed to ingest plant foods grown in a garden in the area and to ingest meat and milk from livestock raised in the area. All water used by the farmer for drinking, household use, irrigation, and livestock watering is from a well located within the area.

Case A (reactor biological shield) considers only the contribution from the radionuclides present in the activated concrete of the reactor biological shield. Case A does not include the radionuclides from the reactor vessel or the steam generators but does include the radionuclides from the reinforcing steel and piping embedded in the concrete. The reactor biological shield is modeled as a $3-\mathrm{m}$-tall concrete cylinder with a $2-\mathrm{m}$ radius. The shield is assumed to be buried under $5 \mathrm{~m}$ of soil.

Case $\mathrm{B}$ (contaminated rubble) considers the radioactivity in the concrete floors of the facility, including radioactivity inside embedded piping and the spent-fuel basin. These structures are assumed to be demolished, resulting in rubble occupying a cylindrical volume $4.9 \mathrm{~m}$ thick with a $10.5-\mathrm{m}$ radius. The rubble is assumed to be buried under $12.5 \mathrm{~m}$ of soil.

Case C (contaminated rubble, installed equipment, and reactor biological shield) considers the total residual radioactivity in both the contaminated rubble and the reactor biological shield. In addition, this scenario includes the radioactivity associated with the all of the installed equipment except the reactor vessel and the steam generators. The source geometry is assumed to be the same as that for case B.

Case D (contaminated well cuttings) considers a new source that would be generated by drilling a well at the downgradient edge of the source considered in case $C$. In the process, some of the contaminated material would be brought up to the surface and is assumed to be spread over the land surface. The soil from the well cuttings is then assumed to be plowed down to $15 \mathrm{~cm}$ below the surface. 
TABLE A.1 Parameters Used in the RESRAD Computer Code to Analyze the Potential Radiation Doses from Residual Radioactivity at the HWCTR Site

Case

RESRAD Parameter

Area of contaminated zone $\left(\mathrm{m}^{2}\right)$

Thickness of contaminated zone (m)

Length parallel to aquifer flow (m)

Basic radiation dose limit (mrem/yr)

Time since placement of material (yr)

Time for calculations (yr)

Time for calculations (yr)

Time for calculations (yr)

Time for calculations (yr)

Time for calculations (yr)

Time for calculations (yr)

Time for calculations ( $\mathrm{yr}$ )

Time for calculations (yr)

Initial principal radionuclide $(\mathrm{pCi} / \mathrm{g})$

Am-241
Ba-133
C-14
Co-60
Cs-137
Eu-152
Eu-154
H-3
Ni-59
Ni-63
Pu-238
Pu-239
Sr-90
U-234
U-235
U-238

Cover depth (m)

Density of cover material $\left(\mathrm{g} / \mathrm{cm}^{3}\right)$

Cover depth erosion rate $(\mathrm{m} / \mathrm{yr})$

Density of contaminated zone $\left(\mathrm{g} / \mathrm{cm}^{3}\right)$

Contaminated zone erosion rate $(\mathrm{m} / \mathrm{yr})$

Contaminated zone total porosity ${ }^{f}$

Contaminated zone effective porosity ${ }^{\mathrm{f}}$

\begin{tabular}{|c|c|c|c|c|}
\hline $\mathrm{A}^{\mathrm{a}}$ & $\mathrm{B}^{\mathrm{b}}$ & $\mathrm{C}^{\mathrm{c}}$ & $D^{d}$ & Default \\
\hline 12.4 & 346 & 346 & 200 & 10,000 \\
\hline 3 & 4.9 & 4.9 & 0.15 & 2 \\
\hline 4 & 21 & 21 & 14 & 100 \\
\hline 30 & 30 & 30 & 30 & 30 \\
\hline 0 & 0 & 0 & 0 & 0 \\
\hline 30 & 30 & 30 & 1 & 1 \\
\hline 100 & 100 & 100 & 2 & 3 \\
\hline 300 & 300 & 300 & 4 & 10 \\
\hline 1,000 & 1,000 & 1,000 & 8 & 30 \\
\hline 3,000 & 3,000 & 3,000 & 16 & 100 \\
\hline 10,000 & 10,000 & 10,000 & 32 & 300 \\
\hline $\mathrm{NA}^{\mathrm{e}}$ & NA & NA & 64 & 1,000 \\
\hline $\mathrm{NA}$ & NA & NA & 100 & NA \\
\hline 0.032 & $2.1 \times 10^{-5}$ & 0.14 & 0.00045 & 0 \\
\hline 1,200 & NA & 36 & 0.025 & NA \\
\hline 0.0066 & 0.12 & 0.15 & 0.00041 & 0 \\
\hline 7,000 & 0.013 & 220 & 0.014 & 0 \\
\hline 0.013 & 1.6 & 1.6 & 0.0027 & 0 \\
\hline 640 & NA & 20 & 0.014 & 0 \\
\hline 40 & NA & 1.2 & 0.00038 & 0 \\
\hline 19 & 0.2 & 2 & 0.00085 & 0 \\
\hline 0.045 & $2.9 \times 10^{-5}$ & 0.2 & 0.00068 & 0 \\
\hline 3.6 & 0.0023 & 16 & 0.044 & 0 \\
\hline 0.0019 & $2 \times 10^{-6}$ & 0.0085 & $2.3 \times 10^{-5}$ & 0 \\
\hline 0.016 & 0.00018 & 0.068 & 0.00023 & 0 \\
\hline 0.34 & 0.11 & 1.6 & 0.0025 & 0 \\
\hline $3.6 \times 10^{-6}$ & 0.0082 & 0.008 & $2.7 \times 10^{-5}$ & 0 \\
\hline 0 & 0.00028 & 0.00027 & $9.1 \times 10^{-7}$ & 0 \\
\hline $7.8 \times 10^{-6}$ & 0.0062 & 0.006 & $2.0 \times 10^{-5}$ & 0 \\
\hline 5 & 12.5 & 12.5 & 0 & 0 \\
\hline 1.44 & 1.44 & 1.44 & NA & 1.5 \\
\hline $9 \times 10^{-5}$ & $9 \times 10^{-5}$ & $9 \times 10^{-5}$ & $\mathrm{NA}$ & 0.001 \\
\hline 2.4 & 1.64 & 1.7 & 1.44 & 1.5 \\
\hline 0 & 0 & 0 & 0 & 0.001 \\
\hline 0.43 & 0.43 & 0.43 & 0.43 & 0.4 \\
\hline 0.33 & 0.33 & 0.33 & 0.33 & 0.2 \\
\hline
\end{tabular}




\begin{tabular}{|c|c|c|c|c|c|}
\hline \multirow[b]{2}{*}{ RESRAD Parameter } & \multicolumn{4}{|c|}{ Case } & \multirow[b]{2}{*}{ Default } \\
\hline & $\mathrm{A}^{\mathrm{a}}$ & $\mathrm{B}^{\mathrm{b}}$ & $C^{c}$ & $D^{d}$ & \\
\hline $\begin{array}{l}\text { Contaminated zone hydraulic conductivity } \\
\text { (m/yr) }\end{array}$ & 1.52 & 1.52 & 1.52 & 1.52 & 10 \\
\hline Contaminated zone $b$ parameter ${ }^{\mathrm{f}}$ & 5.3 & 5.3 & 5.3 & 5.3 & 5.3 \\
\hline Humidity in air $\left(\mathrm{g} / \mathrm{cm}^{3}\right)$ & 11 & 11 & 11 & 11 & 8 \\
\hline Evapotranspiration coefficient ${ }^{\mathrm{f}}$ & 0.91 & 0.91 & 0.91 & 0.91 & 0.5 \\
\hline Precipitation $(\mathrm{m} / \mathrm{yr})$ & 1.2 & 1.2 & 1.2 & 1.2 & 1 \\
\hline Irrigation $(\mathrm{m} / \mathrm{yr})$ & 0.76 & 0.76 & 0.76 & 0.76 & 0.2 \\
\hline Irrigation mode & Overhead & Overhead & Overhead & Overhead & Overhead \\
\hline Runoff coefficient ${ }^{\mathrm{f}}$ & 0.4 & 0.4 & 0.4 & 0.4 & 0.2 \\
\hline Watershed area for nearby stream or pond $\left(\mathrm{m}^{2}\right)$ & $1,000,000$ & $1,000,000$ & $1,000,000$ & $1,000,000$ & $1,000,000$ \\
\hline Accuracy for water/soil computations & 0.001 & 0.001 & 0.001 & 0.001 & 0.001 \\
\hline Density of saturated zone $\left(\mathrm{g} / \mathrm{cm}^{3}\right)$ & 1.44 & 1.44 & 1.44 & 1.44 & 1.5 \\
\hline Saturated zone total porosity ${ }^{\mathrm{f}}$ & 0.43 & 0.43 & 0.43 & 0.43 & 0.4 \\
\hline Saturated zone effective porosity ${ }^{\mathrm{f}}$ & 0.33 & 0.33 & 0.33 & 0.33 & 0.2 \\
\hline Saturated zone hydraulic conductivity (m/yr) & 546 & 546 & 546 & 546 & 100 \\
\hline Saturated zone hydraulic gradient ${ }^{\mathrm{f}}$ & 0.0035 & 0.0035 & 0.0035 & 0.0035 & 0.02 \\
\hline Saturated zone $\mathrm{b}$ parameter $\mathrm{f}^{\mathrm{f}}$ & 5.3 & 5.3 & 5.3 & 5.3 & 5.3 \\
\hline Water table drop rate $(\mathrm{m} / \mathrm{yr})$ & 0 & 0 & 0 & 0 & 0.001 \\
\hline Well pump intake depth (m below water table) & 6.1 & 6.1 & 6.1 & 6.1 & 10 \\
\hline $\begin{array}{l}\text { Model: nondispersion (ND) or mass-balance } \\
\quad(\mathrm{MB})\end{array}$ & ND & $\mathrm{ND}$ & ND & ND & ND \\
\hline Well pumping rate $\left(\mathrm{m}^{3} / \mathrm{yr}\right)$ & 250 & 250 & 250 & 250 & 250 \\
\hline Number of unsaturated zone strata & 1 & 1 & 1 & 1 & 1 \\
\hline Unsaturated zone 1 thickness (m) & 24.9 & 15.5 & 15.5 & 32.9 & 4 \\
\hline Unsaturated zone 1 soil density $\left(\mathrm{g} / \mathrm{cm}^{3}\right)$ & 1.44 & 1.44 & 1.44 & 1.44 & 1.5 \\
\hline Unsaturated zone 1 total porosity ${ }^{\mathrm{f}}$ & 0.43 & 0.43 & 0.43 & 0.43 & 0.4 \\
\hline Unsaturated zone 1 effective porosity $^{\mathrm{f}}$ & 0.33 & 0.33 & 0.33 & 0.33 & 0.2 \\
\hline Unsaturated zone 1 soil-specific b parameter ${ }^{f}$ & 5.3 & 5.3 & 5.3 & 5.3 & 5.3 \\
\hline $\begin{array}{l}\text { Unsaturated zone } 1 \text { hydraulic conductivity } \\
(\mathrm{m} / \mathrm{yr})\end{array}$ & 1.52 & 1.52 & 1.52 & 1.52 & 10 \\
\hline \multicolumn{6}{|l|}{ Distribution coefficient: all zones $\left(\mathrm{cm}^{3} / \mathrm{g}\right)$} \\
\hline Am-241 & 1,900 & 1,900 & 1,900 & 1,900 & 20 \\
\hline $\mathrm{Ba}-133$ (as $\mathrm{Sr}-90$ ) & 10 & NA & 10 & 10 & NA \\
\hline C-14 & 2 & 2 & 2 & 2 & 0 \\
\hline Co-60 & 10 & 10 & 10 & 10 & 1,000 \\
\hline Cs-137 & 330 & 330 & 330 & 330 & 1,000 \\
\hline $\mathrm{Eu}-152$ & 245 & NA & 245 & 245 & $-1^{\mathrm{g}}$ \\
\hline $\mathrm{Eu}-154$ & 245 & NA & 245 & 245 & $-1^{g}$ \\
\hline $\mathrm{H}-3$ & 1 & 1 & 1 & 1 & 0 \\
\hline
\end{tabular}


Case

\begin{tabular}{|c|c|c|c|c|c|}
\hline RESRAD Parameter & $\mathrm{A}^{\mathrm{a}}$ & $\mathrm{B}^{\mathrm{b}}$ & $\mathrm{C}^{\mathrm{c}}$ & $\mathrm{D}^{\mathrm{d}}$ & Default \\
\hline \multicolumn{6}{|l|}{ Distribution coefficient: all zones $\left(\mathrm{cm}^{3} / \mathrm{g}\right)($ Cont. $)$} \\
\hline $\mathrm{Ni}-59$ & 400 & 400 & 400 & 400 & 1,000 \\
\hline $\mathrm{Ni}-63$ & 400 & 400 & 400 & 400 & 1,000 \\
\hline $\mathrm{Pu}-238$ & 100 & 100 & 100 & 100 & 2,000 \\
\hline Pu-239 & 100 & 100 & 100 & 100 & 2,000 \\
\hline $\mathrm{Sr}-90$ & 10 & 10 & 10 & 10 & 30 \\
\hline U-234 & 35 & 35 & 35 & 35 & 50 \\
\hline $\mathrm{U}-235$ & NA & 35 & 35 & 35 & 50 \\
\hline $\mathrm{U}-238$ & 35 & 35 & 35 & 35 & 50 \\
\hline Daughter Ac-227 & 400 & 400 & 400 & 400 & 20 \\
\hline Daughter Gd-152 & $-1^{g}$ & NA & $-1^{g}$ & $-1^{g}$ & $-1^{\mathrm{g}}$ \\
\hline Daughter Np-237 & 5 & 5 & 5 & 5 & $-1^{g}$ \\
\hline Daughter $\mathrm{Pa}-231$ & 550 & 550 & 550 & 550 & 50 \\
\hline Daughter $\mathrm{Pb}-210$ & 55 & 55 & 55 & 55 & 100 \\
\hline Daughter Ra-226 & 500 & 500 & 500 & 500 & 70 \\
\hline Daughter Th-229 & 3,000 & 3,000 & 3,000 & 3,000 & 60,000 \\
\hline Daughter Th-230 & 3,000 & 3,000 & 3,000 & 3,000 & 60,000 \\
\hline Daughter U-233 & 35 & 35 & 35 & 35 & 50 \\
\hline Daughter U-235 & 35 & NA & NA & $\mathrm{NA}$ & 50 \\
\hline Inhalation rate $\left(\mathrm{m}^{3} / \mathrm{yr}\right)$ & 8,000 & 8,000 & 8,000 & 8,000 & 8,400 \\
\hline Mass loading for inhalation $\left(\mathrm{g} / \mathrm{m}^{3}\right)$ & 0.0001 & 0.0001 & 0.0001 & 0.0001 & 0.0001 \\
\hline Dilution length for airborne dust inhalation (m) & 3 & 3 & 3 & 3 & 3 \\
\hline Exposure duration $(\mathrm{yr})$ & 30 & 30 & 30 & 30 & 30 \\
\hline Shielding factor, inhalation ${ }^{\mathrm{f}}$ & 0.4 & 0.4 & 0.4 & 0.4 & 0.4 \\
\hline Shielding factor, external gamma ${ }^{f}$ & 0.7 & 0.7 & 0.7 & 0.7 & 0.7 \\
\hline Fraction of time spent indoors & 0.5 & 0.5 & 0.5 & 0.5 & 0.5 \\
\hline Fraction of time spent outdoors (on-site) & 0.25 & 0.25 & 0.25 & 0.25 & 0.25 \\
\hline Shape factor flag, external gamma & 1 & 1 & 1 & 1 & 1 \\
\hline $\begin{array}{l}\text { Fruits, vegetables, and grain consumption } \\
\qquad(\mathrm{kg} / \mathrm{yr})\end{array}$ & 163 & 163 & 163 & 163 & 160 \\
\hline $\begin{array}{l}\text { Leafy vegetables and vegetable consumption } \\
\qquad(\mathrm{kg} / \mathrm{yr})\end{array}$ & 21 & 21 & 21 & 21 & 14 \\
\hline Milk consumption $(\mathrm{L} / \mathrm{yr})$ & 120 & 120 & 120 & 120 & 92 \\
\hline Meat and poultry consumption $(\mathrm{kg} / \mathrm{yr})$ & 43 & 43 & 43 & 43 & 63 \\
\hline Fish consumption $(\mathrm{kg} / \mathrm{yr})$ & NA & NA & NA & NA & 5.4 \\
\hline Other seafood consumption ( $\mathrm{kg} / \mathrm{yr})$ & NA & NA & NA & NA & 0.9 \\
\hline Soil ingestion rate $(g / y r)$ & 36.5 & 36.5 & 36.5 & 36.5 & 36.5 \\
\hline Drinking water intake (L/yr) & 730 & 730 & 730 & 730 & 510 \\
\hline
\end{tabular}


$\mathrm{A}^{\mathrm{a}}$

$\mathrm{B}^{\mathrm{b}}$

$\mathrm{C}^{\mathrm{c}}$

$D^{d} \quad$ Default

Contamination fraction of:

Drinking water

Household water

Livestock water

Irrigation water

Aquatic food

Plant food ${ }^{\mathrm{h}}$

Meat $^{\mathrm{h}}$

Milk $^{\mathrm{h}}$

Livestock fodder intake for meat $(\mathrm{kg} / \mathrm{d})$

Livestock fodder intake for milk ( $\mathrm{kg} / \mathrm{d})$

Livestock water intake for meat $(\mathrm{L} / \mathrm{d})$

Livestock water intake for milk (L/d)

Livestock soil intake $(\mathrm{kg} / \mathrm{d})$

Mass loading for foliar deposition $\left(\mathrm{g} / \mathrm{m}^{3}\right)$

Depth of soil mixing layer $(\mathrm{m})$

Depth of roots $(\mathrm{m})$

Fraction from groundwater:

Drinking water

Household water

Livestock water

Irrigation water

Wet weight crop yield $\left(\mathrm{kg} / \mathrm{m}^{2}\right)$

Nonleafy vegetables

Leafy vegetables

Fodder

Growing season (yr)

Nonleafy vegetables

Leafy vegetables

Fodder

Translocation factor

Nonleafy vegetables

Leafy vegetables

Fodder

Dry foliar interception fraction

Nonleafy vegetables

Leafy vegetables

Fodder

\begin{tabular}{|c|c|}
\hline 1 & 1 \\
\hline 1 & 1 \\
\hline 1 & 1 \\
\hline 1 & 1 \\
\hline NA & $\mathrm{NA}$ \\
\hline
\end{tabular}

$1 \quad 1 \quad 1$

$\begin{array}{lll}1 & 1 & 1\end{array}$

$1 \quad 1 \quad 1$

$\begin{array}{lll}1 & 1 & 1 \\ 1 & 1 & 1\end{array}$

NA NA $\quad 0.5$

$\begin{array}{lllll}0.062 & 0.173 & 0.173 & 0.1 & -1^{\mathrm{g}}\end{array}$

$\begin{array}{lllll}0.0062 & 0.0173 & 0.0173 & 0.01 & -1^{\mathrm{g}}\end{array}$

$\begin{array}{lllll}0.0062 & 0.0173 & 0.0173 & 0.01 & -1^{\mathrm{g}}\end{array}$

$\begin{array}{lllll}44 & 44 & 44 & 44 & 68\end{array}$

$\begin{array}{lllll}44 & 44 & 44 & 44 & 55\end{array}$

$50 \quad 50 \quad 50 \quad 50 \quad 50$

$\begin{array}{lllll}160 & 160 & 160 & 160 & 160\end{array}$

$\begin{array}{lllll}0.5 & 0.5 & 0.5 & 0.5 & 0.5\end{array}$

$\begin{array}{lllll}0.0001 & 0.0001 & 0.0001 & 0.0001 & 0.0001\end{array}$

$\begin{array}{lllll}0.15 & 0.15 & 0.15 & 0.15 & 0.15\end{array}$

$\begin{array}{lllll}0.9 & 0.9 & 0.9 & 0.9 & 0.9\end{array}$

$\begin{array}{lllll}1 & 1 & 1 & 1 & 1\end{array}$

$\begin{array}{lllll}1 & 1 & 1 & 1 & 1\end{array}$

$\begin{array}{lllll}1 & 1 & 1 & 1 & 1\end{array}$

$\begin{array}{lllll}1 & 1 & 1 & 1 & 1\end{array}$

$\begin{array}{lllll}0.7 & 0.7 & 0.7 & 0.7 & 0.7 \\ 1.5 & 1.5 & 1.5 & 1.5 & 1.5 \\ 1.1 & 1.1 & 1.1 & 1.1 & 1.1\end{array}$

$\begin{array}{lllll}0.17 & 0.17 & 0.17 & 0.17 & 0.17 \\ 0.25 & 0.25 & 0.25 & 0.25 & 0.25 \\ 0.08 & 0.08 & 0.08 & 0.08 & 0.08\end{array}$

$\begin{array}{ccccc}0.1 & 0.1 & 0.1 & 0.1 & 0.1 \\ 1 & 1 & 1 & 1 & 1 \\ 1 & 1 & 1 & 1 & 1\end{array}$

$\begin{array}{lllll}0.25 & 0.25 & 0.25 & 0.25 & 0.25 \\ 0.25 & 0.25 & 0.25 & 0.25 & 0.25 \\ 0.25 & 0.25 & 0.25 & 0.25 & 0.25\end{array}$


TABLE A.1 (Cont.)

Case

RESRAD Parameter

$\mathrm{A}^{\mathrm{a}} \quad \mathrm{B}^{\mathrm{b}}$

$\mathrm{C}^{\mathfrak{c}}$

$D^{d}$

Default

Wet foliar interception fraction

Nonleafy vegetables

0.25

0.25

0.25

0.25

0.25

Leafy vegetables

0.25

0.25

0.25

0.25

0.25

Fodder

0.25

0.25

0.25

0.25

0.25

Weathering removal constant for vegetation $\left(\mathrm{yr}^{-1}\right)$

C-12 concentration in water $\left(\mathrm{g} / \mathrm{cm}^{3}\right)$

$\mathrm{C}-12$ concentration in contaminated soil $(\mathrm{g} / \mathrm{g})$

0.00002

20

20

20

20

0.03

0.00002

0.00002

0.00002

0.00002

Fraction of vegetation carbon from soil

Fraction of vegetation carbon from air

0.02

0.03

0.03

0.03

0.03

0.98

0.02

0.02

0.02

0.02

0.3

0.98

0.98

0.98

0.98

$\mathrm{C}-14$ evasion layer thickness in soil (m)

$\mathrm{C}-14$ evasion flux rate from soil $\left(\mathrm{s}^{-1}\right)$

$\mathrm{C}-12$ evasion flux rate from soil $\left(\mathrm{s}^{-1}\right)$

Fraction of grain in beef cattle feed

Fraction of grain in milk cow feed

Storage times of contaminated foodstuffs (d)

Fruits, nonleafy vegetables, and grain

Leafy vegetables

Milk

Meat and poultry

Fish

Crustaceans and mollusks

Well water

Surface water

Livestock fodder

Thickness of building foundation (m)

Bulk density of building foundation $\left(\mathrm{g} / \mathrm{cm}^{3}\right)$

Total porosity of the cover material ${ }^{\mathrm{f}}$

Total porosity of the building foundation ${ }^{\mathrm{f}}$

Volumetric water content of the cover material

Volumetric water content of the foundation

Diffusion coefficient for radon gas $\left(\mathrm{m}^{2} / \mathrm{s}\right)$

Cover material

Foundation material

Contaminated zone soil

Radon vertical dimension of mixing (m)

Average annual wind speed $(\mathrm{m} / \mathrm{s})$

Average building air exchange rate $\left(h^{-1}\right)$

Height of the building (room) (m)

$7 \times 10^{-7} \quad 7 \times 10^{-7}$

0.3

0.3

0.3

$1 \times 10^{-10}$

$7 \times 10^{-7}$

$7 \times 10^{-7}$

$7 \times 10^{-7}$

0.75

$1 \times 10^{-10}$

$1 \times 10^{-10}$

$1 \times 10^{-10}$

$1 \times 10^{-10}$

0.56

0.75

0.75

0.75

0.8

0.56

0.56

0.56

0.2

$\begin{array}{ccccc}14 & 14 & 14 & 14 & 14 \\ 1 & 1 & 1 & 1 & 1 \\ 3 & 3 & 3 & 3 & 1 \\ 6 & 6 & 6 & 6 & 20 \\ \text { NA } & \text { NA } & \text { NA } & \text { NA } & 7 \\ \text { NA } & \text { NA } & \text { NA } & \text { NA } & 7 \\ 1 & 1 & 1 & 1 & 1 \\ 1 & 1 & 1 & 1 & 1 \\ 45 & 45 & 45 & 45 & 45 \\ 0.15 & 0.15 & 0.15 & 0.15 & 0.15 \\ 2.4 & 2.4 & 2.4 & 2.4 & 2.4 \\ 0.4 & 0.4 & 0.4 & 0.4 & 0.4 \\ 0.1 & 0.1 & 0.1 & 0.1 & 0.1 \\ 0.05 & 0.05 & 0.05 & 0.05 & 0.05 \\ 0.03 & 0.03 & 0.03 & 0.03 & 0.03\end{array}$

$\begin{array}{ccccc}2 \times 10^{-6} & 2 \times 10^{-6} & 2 \times 10^{-6} & 2 \times 10^{-6} & 2 \times 10^{-6} \\ 3 \times 10^{-7} & 3 \times 10^{-7} & 3 \times 10^{-7} & 3 \times 10^{-7} & 3 \times 10^{-7} \\ 2.5 \times 10^{-8} & 2.5 \times 10^{-8} & 2.5 \times 10^{-8} & 2.5 \times 10^{-8} & 2.5 \times 10^{-6} \\ 2 & 2 & 2 & 2 & 2 \\ 2 & 2 & 2 & 2 & 2 \\ 0.5 & 0.5 & 0.5 & 0.5 & 0.5 \\ 2.5 & 2.5 & 2.5 & 2.5 & 2.5 \\ 0 & 0 & 0 & 0 & 0\end{array}$

Building interior area factor ${ }^{f}$ 
TABLE A.1 (Cont.)

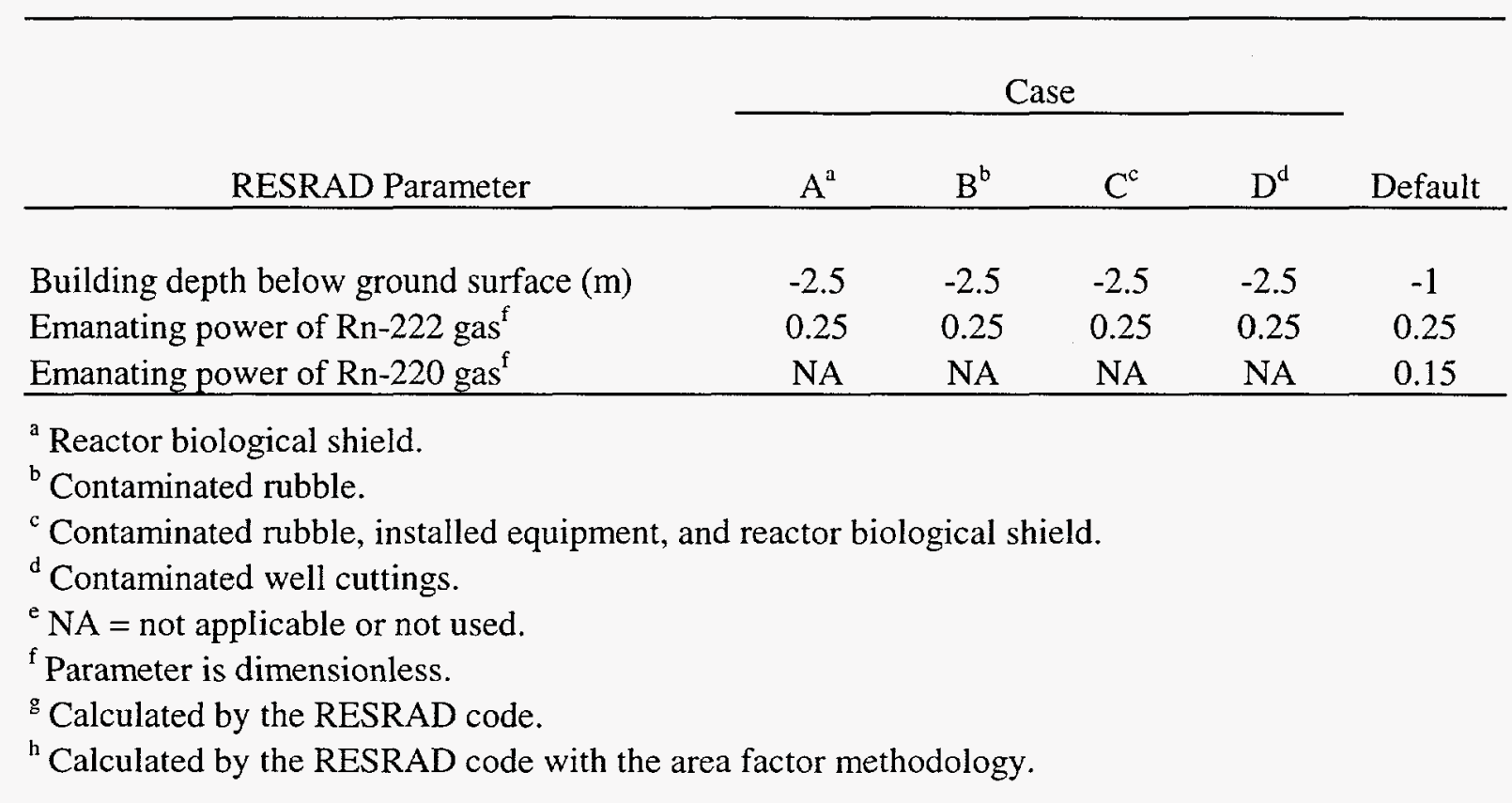

\section{REFERENCES FOR APPENDIX}

Smith, R., and J. McNeil, 1997, Residual Radioactivity Guidelines for the Heavy Water Components Test Reactor at the Savannah River Site, Westinghouse Savannah River Company, Aiken, S.C., April.

Yu, C., et al., 1993, Manual for Implementing Residual Radioactive Material Guidelines Using RESRAD, Version 5.0, ANL/EAD/LD-2, Argonne National Laboratory, Environmental Assessment Division, Argonne, Ill., Sept. 